\title{
Vállalati dinamika és aggregált növekedés Magyarországon*
}

\author{
Bauer Péter - Endrész Marianna
}

A tanulmány a vállalati dinamika magyarországi stilizált tényeit mutatja be a 20012015-ös időszak adatain. Azt találjuk, hogy a fiatal vállalatok többnyire kisméretüek. Gyorsan növekednek, ugyanakkor kockázatosak, magas közöttük a megszünő vállalatok aránya és termelékenységük alacsonyabb, mint az idősebb vállalatoké. Bár a fiatal vállalatoknak alacsony a részesedése az aggregált kibocsátásból, az aggregált növekedéshez jelentős a hozzájárulásuk. Dinamizmusuk inkább fiatal korukból, mintsem kis méretükből származik. Az exportteljesítmény ettől némileg eltérő képet mutat, mivel az exportáló idősebb vállalatok aktívabbak maradnak, ezért érdemi a hozzájárulásuk az aggregált növekedéshez. A fiatal vállalatok hozzájárulása a növekedéshez a válság alatt is pozitiv volt, de ekkor az aggregált képet az idősebb cégek romló teljesítménye dominálta, termelésböl való nagy részesedésük miatt. Az egyes vállalati szegmensek viselkedése méret és kor szerint különbözött a válság, ill. a kilábalás alatt. Érdekes módon úgy tünik, hogy a kilábalást a vállalati sokaság eloszlásának alsó széle dominálta: a rombolás enyhült, és kevesebb vállalat szünt meg, de a bruttó teremtésben nem volt javulás. A vállalatalapítási kedv tovább csökkent még a kilábalás alatt is, ami hozzájárulhatott a lassú és gyenge kilábaláshoz.

Journal of Economic Literature (JEL) kódok: D22, L25

Kulcsszavak: vállalati dinamika, vállalati életciklus, válság, gazdasági növekedés, empirikus elemzés

\section{Bevezetés}

A gazdasági növekedés forrásainak és korlátjainak elemzése a gazdaságpolitikai kutatások kiemelt témája. Az irodalom nagyon gazdag, a növekedés számos tényezőjét lefedi: intézmények, verseny, technológiai hullámok, innováció és nemzetközi kereskedelem. Ebben a tanulmányban a vállalati dinamikára és aggregált növekedéssel való kapcsolatára, a növekedésre gyakorolt hatására koncentrálunk. Mit tehet hozzá a vállalati szintű elemzés az aggregált növekedés megértéséhez? A vállalatok

\footnotetext{
* A jelen kiadványban megjelenő írások a szerzők nézeteit tartalmazzák, ami nem feltétlenül egyezik a Magyar Nemzeti Bank hivatalos álláspontjával.

Bauer Péter a Magyar Nemzeti Bank vezető közgazdasági elemzője. E-mail: bauerp@mnb.hu Endrész Marianna a Magyar Nemzeti Bank közgazdasági kutatási szakértője. E-mail: valentinyinem@mnb.hu Az angol nyelvű kézirat első változata 2017. december 19-én érkezett szerkesztőségünkbe.
}

DOI: http://doi.org/10.25201/HSZ.17.2.6898 
viselkedése heterogén, dinamikájuk kor és méret szerint változik, a vállalatalapítás (továbbiakban belépés) és megszűnés (továbbiakban kilépés) fontos meghatározói lehetnek az aggregált növekedés szintjének és dinamikájának. A vállalati dinamikának és időbeli alakulásának vizsgálatával ezért jobban megérthetjük, honnan származik a növekedés, milyen különbségek jellemzők az üzleti ciklus egyes fázisaiban, mik a növekedés korlátai. Lehetővé teszi például a következő típusú kérdések vizsgálatát: a kis vagy a fiatal vállalatok növekednek gyorsan? A belépés költségei magasak vagy inkább a növekedés az, ami korlátokba ütközik? Hogyan változott a vállalati dinamika a pénzügyi válság során? Ezen kérdések megválaszolása segítheti a növekedés forrásainak és korlátainak azonosítását és a növekedést ösztönző gazdaságpolitikák kialakítását. Jelen tanulmány alapvető megfigyeléseket tesz a vállalati dinamikára vonatkozóan, amely az első lépés a fenti irányba.

A vállalati dinamikára vonatkozó empirikus irodalom a következő megfigyeléseket teszi: (1) a fiatal vállalatok jellemzően kisméretűek, és a méreteloszlásuk ferde; (2) a kisméretű vállalatok nagyobb valószínűséggel lépnek ki, de azok, melyek túlélnek, gyorsabban növekednek, mint a nagy vállalatok; (3) a kor és a méret pozitívan korrelál; (4) a termelési tényezők reallokációja a kevésbé termelékeny vállalatoktól a termelékenyebb vállalatokhoz, ill. az új belépőkhöz a termelékenység növekedésének fő forrása (Id. Bartelsman et al. 2004; López-Garcia és Puente 2006; Békés et al. 2011; Andersson 2006). A méret és növekedés közötti kapcsolatra vonatkozó eredményeket később Haltiwanger et al. (2013) és Criscuolo et al. (2014) megkérdőjelezte. Az idézett tanulmányok megmutatták, hogy a kisméretű vállalatok jelentősége a munkahelyteremtésben inkább fiatal koruk következménye, kevésbé származik méretükből. A fenti empirikus jelenségeket legjobban magyarázó elméleti modellek a schumpeteri növekedési elméletek, amelyek a teremtő rombolás fogalmára alapoznak (Id. Aghion et al. 2014). Schumpeter az innovációt tekintette a növekedés motorjának. Amint az új technológiák helyettesítik a régieket, a növekedés a teremtő romboláson keresztül valósul meg. Ez a teremtő rombolás magában foglalja az új vállalatok belépését, az inputok reallokációját, és többnyire konzisztens a vállalati dinamika empirikus megfigyeléseivel.

A magyar adatokon alapuló kapcsolódó irodalom az aggregált termelékenység felbontására fókuszál. Békés és szerzőtársai (2011) a feldolgozóipart vizsgálják az 19962006-os időszakban. Azt találják, hogy az aggregált termelékenység növekedésének fő oka a folyamatosan létező vállalatokon belül történő termelékenységnövekedés, bár az inputok reallokációjának, a teremtő rombolásnak is volt némi pozitív hatása. Brown és Earle (2008) feldolgozóipari vállalatok adatait elemzi néhány tranzíciós országra, így Magyarországra vonatkozóan is, bemutatva a reallokáció változását az átmenetet követően.

Ebben a tanulmányban a 2001-2015-ös időszak vállalati szintű adatait használjuk a vállalati dinamika néhány jellemzőjének magyarországi vizsgálatához, a legutóbbi 
pénzügyi válság hatását is bemutatva. A vizsgálat az aggregált növekedésre koncentrál. Elemezzük a vállalatok növekedési teljesítményét és annak kapcsolatát a korral. Haltiwanger és szerzőtársai $(2013,2016)$ munkáit követve tárgyaljuk, hogy a méret vagy a kor fontosabb a növekedés szempontjából. A legutóbbi válság során a vállalatok belépése számos országban historikusan alacsony szintre zuhant, ami tartós lassulást és gyenge kilábalást okozott. Így megvizsgáljuk a belépés és kilépés szerepét általában és a válság-kilábalás periódusában is. Elemzésünk a vállalati életciklusok irodalmára is épít: a belépésen, kilépésen és output növekedésen túl megvizsgáljuk a vállalati teljesítmény egyéb mutatóit - export, termelékenység és banki hitelfelvétel -, ill. ezek változását a vállalati kor függvényében.

Magyar adatokon ez az első ilyen tanulmány. Majdnem a teljes vállalati sokaságot lefedjük. A vállalati dinamikával foglalkozó irodalomtól eltérően nem a munkahelyteremtésre mint növekedési mutatóra fókuszálunk, hanem a reál hozzáadott érték növekedésére. Adatbázisunk újszerű abban a tekintetben, hogy teljes mértékben figyelembe vesszük a vállalatátalakulásokat, ide értve a fúziókat és felvásárlásokat, illetve az egy-az-egy típusú átváltozásokat. Nem foglalkozunk ugyanakkor a termelékenység felbontásával, ami egyébként természetes kiterjesztése lenne a tanulmánynak, és jövőbeli kutatásoknak lehet a tárgya.

A következő fejezet bemutatja a felhasznált adatbázist és a módszertant. Az azt követő fejezetekben egy-egy teljesítménymutatót vizsgálunk, kapcsolatukat a korral, viselkedésüket a különböző időszakokban, és foglalkozunk a „kor vagy méret” vitával. A reál hozzáadott értékkel kezdünk, ezt követi a termelékenység, export és a banki hitelfelvétel. A következtetésekkel zárjuk a tanulmányt.

\section{Adatok és módszertan}

Három adatbázist használunk elemzéseink során: a kettős könyvelésú vállalatok éves mérleg- és eredménykimutatását a Nemzeti Adó- és Vámhivataltól (NAV), a vállalati regisztert a Központi Statisztikai Hivataltól (KSH) és a banki hitelezési adatokat a Központi Hitelinformációs Rendszerből (KHR).

A fóbb vállalati szintű változók létrehozásához a mérleg és jövedelemkimutatás adatait használjuk. Ebből következően elemzéseink éves gyakoriságú adatokon történnek, a 2001 és 2015 közötti időszakra. Hozzáadott értéket az árbevételből és különféle költségelemekből számolunk. A vállalatokat 2 számjegyű ágazatokba soroljuk a 4 számjegyű TEÁOR besorolásuk alapján. Adatproblémák miatt a pénzügyi szektort és az olajipart kihagyjuk. A nominális változókat a hivatalos 2 számjegyü, ágazati szintű deflátorokkal defláljuk, így kapjuk a reálváltozókat (a hozzáadott érték esetében a hozzáadott érték implicit árindexeit, az export esetében pedig a termelői árindexet használjuk deflálásra). A munkatermelékenységet a foglalkoztatásból és a reál hozzáadott értékből számoljuk. 
A vállalatok méretkategóriába sorolásához felhasználjuk a mérlegfőösszegre, az árbevételre és a foglalkoztatásra vonatkozó adatokat. Mikro-, kis-, közép- és nagyvállalati kategóriákat definiálunk. Definíciónk nagyon hasonló a hivatalos kkv-besoroláshoz, ahol a küszöbértékek az alábbiak: foglalkoztatás: 10, 50, 250 fő; (nettó) árbevétel: 2, 10, 50 millió euro; mérlegfőösszeg: 2, 10, 43 millió euro. Akkor sorolunk egy vállalatot magasabb kategóriába, ha a három változó bármelyike átlépi a releváns küszöbértéket. Ez különbözik a hivatalos definíciótól, ahol vagy a foglalkoztatásnak, vagy az árbevételnek és mérlegfőösszegnek is át kell lépnie a küszöbértéket. ${ }^{1}$ Abban az esetben, ha a létszám hiányzik, a másik két változó alapján soroljuk be a vállalatot (az árbevétel és a mérlegfőösszeg esetén nincs hiányzó érték).

A KHR-ből két indikátorváltozót számítunk. Ezek azt mutatják, van-e a vállalatnak hitelkapcsolata pénzintézettel. Az egyik változó flow jellegű, amely akkor vesz fel 1-et, ha az adott időszakban új hitelt vesz fel a vállalat, egyébként nulla. A másik stock jellegű változó, amely akkor vesz fel 1-et, ha az adott időszakban van hitele a vállalatnak, egyébként nulla. A KHR adatai 2005-től állnak rendelkezésünkre, így a hitelezés esetében a 2005-2015-ös időszakot tudjuk vizsgálni.

A hozzáadott érték és az export esetében úgynevezett középponti (mid-point) növekedési rátákat használunk, amelyeket Davis, Haltiwanger és Schuh (1996) javasolt, és számos vállalati dinamikával foglalkozó tanulmányban használnak (Id. pl. Haltiwanger et al. 2016). A középponti növekedési ráták a következőképpen számíthatók:

$$
X_{i t}^{g r}=\frac{X_{i t}-X_{i t-1}}{0,5 *\left(X_{i t}+X_{i t-1}\right)}
$$

Ennek a növekedési rátának számos előnye van a hagyományos százalékos változással vagy log-differenciával szemben, bár megjegyezzük, hogy az utóbbi jól közelíti. Az értékkészlete -2 és 2 között van; szimmetrikus abban az értelemben, hogy a $t$. és $t-1$. időszaki érték felcserélésével ugyanazt az értéket kapjuk ellentétes előjellel (ez a log-differenciára is igaz). Ebből az is következik, hogy ha egy növekedést olyan csökkenés követ, amikor az érték visszaáll az eredetire, akkor a növekedési ráták összege zérus lesz. Nagy előnye a középponti növekedési rátának, hogy az $X$ nulla értékeit nem kell kidobni: ${ }^{2}$ a belépők, ill. kilépők növekedési rátája 2, ill. -2 lesz (a log-differencia esetében egyik sem definiált, a százalékos változás csak a kilépés

\footnotetext{
${ }^{1}$ A hivatalos szabálytól való eltérést az indokolja, hogy a multinacionális cégek zöldmezős beruházásaira korrigáljunk. Ebben az esetben ugyanis a leányvállalatok általában nem rendelkeznek még árbevétellel, és csak maroknyi embert foglalkoztatnak, miközben mérlegfőösszegük nagy.

${ }^{2}$ Néhány vállalat hozzáadott értéke negatív. Ezt semmilyen növekedési ráta nem képes kezelni, így a negatív értékeket nullával helyettesítjük. Ennek eredményeképp a teljes reál hozzáadott érték 3-4 százalékkal emelkedik átlagosan, de a dinamikák alig változnak. Egy másik következmény, hogy valószínúleg enyhén alulbecsüljük a csökkenést, ill. növekedést a válság, ill. a kilábalás során, mivel a negatív értékek (és a nulla) közötti változásokat nem vesszük figyelembe.
} 
esetében definiált, ott mindig -100 százalék). ${ }^{3}$ További előny, hogy ez a növekedési ráta egyszerüen aggregálható: ha a középponti növekedési ráták súlyozott átlagát kiszámítjuk a középponti értékekkel (azaz a $t$. és $t-1$. érték átlagával) mint súlyokkal, akkor megkapjuk az aggregált értékek középponti növekedési rátáját: $\left(X_{t}-X_{t-1}\right) /\left(0,5 *\left(X_{t}+X_{t-1}\right)\right)$, ahol $X_{t}=\sum_{i=1}^{n_{t}} X_{i t}$, és $n_{t}$ a vállalatok száma $t$-ben.

A következőkben a középponti növekedési ráta értékeit általában százalékos változásokként értelmezzük, hasonlóan ahhoz az általános gyakorlathoz, ahogy a logaritmikus változásokat szokás interpretálni. Például, ha a középponti növekedési ráta 0,05, akkor azt mondjuk, hogy a növekedési ráta 5 százalék. Az effajta értelmezés torzítása kicsi, amíg a növekedési ráták alacsonyak; pl. az előbbi esetben a tényleges, előző időszakhoz viszonyított növekedés 5,1 százalék. A torzítás ugyanakkor nagy vagy akár végtelen is lehet (abszolút értékben) nagyobb növekedési ráták esetén. Például, ha a középponti növekedési ráta 1, akkor az előző időszakhoz viszonyított tényleges növekedési ráta 200 százalék, és nem 100 százalék. Ha a középponti növekedési ráta 2, akkor a tényleges növekedési ráta végtelen, hiszen ebben az esetben az előző időszaki érték zérus. Emiatt, ha a növekedési ráta 2 vagy -2, akkor ezeket nem fogjuk 200 vagy -200 százalékos növekedésként értelmezni.

A vállalati regisztert használjuk a vállalati kor meghatározásához, az alapítás évét alapul véve. Definíciónk szerint az alapítás évében a vállalat 1 éves (a hasonló tanulmányok egy része 0 -nak veszi ilyenkor a kort). A hozzáadott értéknél a belépést arra az évre definiáljuk, amikor a vállalatot alapították (azaz, amikor 1 éves). Előfordul, hogy a vállalat az alapítás évében még nem ad le beszámolót, ezekben az esetekben akkor tekintjük belépőnek a vállalatot, amikor először megjelenik az adatbázisban. Kivétel a 2004-es év, amikor minden vállalatnak át kellett állnia kettős könyvelésre, így idősebb, korábban egyszeres könyvvitelű cégek jelentek meg az adatbázisban. A vállalatátalakulások szintén kivételt képeznek; a vállalatátalakulások kezeléséről részletesebben a következő bekezdésben írunk. A kilépés a vállalatra vonatkozó utolsó megfigyelés az adatbázisban. Az export esetében ettől eltérő belépési és kilépési definícióval dolgozunk, mivel az exportaktivitás kezdete és vége nem függ össze közvetlenül a vállalat létrejöttével és megszűnésével. Így ebben az esetben a belépés az exportaktivitás kezdetét, a kilépés az exportaktivitás végét jelenti. Eltérően a hozzáadott értéktől, az export esetében többszörös belépés és kilépés is lehetséges.

A vállalati regiszter a vállalatátalakulásokról is tartalmaz információt, így a fúziókról és felvásárlásokról, illetve egyéb átalakulásokról. ${ }^{4}$ Ezeket az információkat felhasználva korrigáljuk a kor, valamint a hozzáadott érték és exportdinamika számítását.

\footnotetext{
${ }^{3} \mathrm{~A}$ belépés esetén megnézzük, hogy az előző évben volt-e megfigyelés. Ha nem, a növekedési rátát 2-nek definiáljuk. A kilépések kezeléséhez mesterséges megfigyeléseket hozunk létre a következő évre, és a növekedési rátát ott -2-nek definiáljuk.

${ }^{4}$ Az egyéb átalakulásokba tartozik a vállalatok szétválása és az egy-az-egy típusú átváltozás.
} 
A vállalatok korát mindig a vállalatátalakulásban részt vevő legidősebb vállalat korát alapul véve határozzuk meg. Például, ha A és $B$ cég fuzionál a $t$. évben, és az új vállalat, $C$ a $t+1$. évben jelenik meg, akkor a $C$ vállalat kora az $A$ és $B$ vállalat közül az idősebb kora plusz egy amiatt, hogy közben eltelt egy év. Továbbá, sem az $A$, sem a $B$ vállalatot nem tekintjük kilépőnek, a C-t pedig nem tekintjük belépőnek. A dinamikákat szintén korrigáljuk az átalakulásoknak megfelelően: a növekedési rátákat úgy számítjuk, hogy konszolidáljuk az átalakulásban részt vevő vállalatokat, a súlyokat (középponti értékeket) pedig úgy határozzuk meg, hogy az aggregált dinamika ne változzon. A fenti példában, ha A és B a t. évben fuzionál, az új vállalat, $C t+1$-ben, akkor a $C$ vállalat hozzáadott értékének növekedési rátáját úgy számítjuk, mint az $A+B$ vállalat együttes hozzáadott értékének $C$ vállalat hozzáadott értékére való növekedését. $A$ vállalatok szétválása esetén, pl. D vállalatból $E$ és $F$ vállalat lesz, az $E$ és $F$ növekedési rátáját a $D$ vállalat hozzáadott értékéből $E+F$ együttes hozzáadott értékére való növekedéseként számítjuk. Ebben az esetben $\mathrm{E}$ és $\mathrm{F}$ növekedési rátája azonos lesz, és a súlyokat úgy határozzuk meg, hogy az E és $\mathrm{F}$ relatív súlyát tükrözze E+F-ben úgy, hogy az aggregált növekedési ráta ne változzék.

Az elemzések során szinte mindig súlyozott növekedési rátákkal dolgozunk (vagy súlyozott szintekkel a termelékenység esetében), vagy pedig súlyozott regressziókat futtatunk annak érdekében, hogy az aggregált hatásokról tudjunk következtetéseket levonni. Súlyok nélkül az eredményeket a nagyszámú mikrovállalat dominálná. A súlyok a középponti értékek ( $t$ és $t-1$ átlaga) a hozzáadott érték és az export esetében, míg a termelékenységnél az adott időszaki létszámot használjuk. A belépés és kilépés esetén a középponti értékeket a vártnak megfelelően számítjuk: a hiányzó értékeket nullának tekintjük, így a súly értéke az első, ill. utolsó megfigyelés értékének fele lesz. Ily módon a dinamikák súlyozott átlaga meg fog egyezni az aggregált értékek (hozzáadott érték vagy export) dinamikájával.

Amikor regressziókat futtatunk, az év fix hatásra és a 2 számjegyű TEÁOR ágazati fix hatásra mindig kontrollálunk. Más magyarázó változókat (kor vagy méret dummyk) a specifikációnak megfelelően adunk hozzá a regressziókhoz.

A következő dimenziók mentén vizsgáljuk a vállalatok teljesítményét: kor, ahol a következő kategóriákat használjuk: 1-től 14 éves korig, évente, és 15 vagy annál idősebb vállalatok (15+ kategória); méret: a szokásos kategóriákat használjuk: mikro-, kis-, közép- és nagyvállalat; idő: 3 szakaszt definiálunk: válság előtt (2001-2007), válság (2008-2012) és kilábalás (2013-2015).

\section{Vállalatméret, dinamika és kor - reál hozzáadott érték}

Először is bemutatjuk a magyarországi vállalati dinamika stilizált jellemzőit méret, kor, növekedés és volatilitás tekintetében. Az életciklus mentén változó vállalati dinamika elemzéséhez a reál hozzáadott érték (Rva) adatokat használjuk. Hasonló 
tanulmányok gyakran a foglalkoztatásra összpontosítanak, míg az egyéb, output-típusú mutatók használata az adatok elérhetőségének problémái miatt ritka (egy kivétel Haltiwanger et al. 2016). Egy másik érv, hogy az Rva-t tanulmányozzuk a foglalkoztatás helyett, hogy a kor és méret hatását a munkahelyteremtésre részletesen vizsgálja Benk - Morvay - Telegdy (2018).

Az új belépők jellemzően kicsik. Az 1. ábra (felső panel) mutatja a kor és a méret közötti pozitív korrelációt. A korreláció akkor is megmarad, ha regressziót futtatunk, amiben időbeli és ágazati fix hatásokra kontrollálunk (a regressziós eredményeket nem mutatjuk be).

Az új belépők nemcsak kicsik, de rendkívül dinamikusak, nagyon magas növekedési rátákat mutatnak létezésük első éveiben (Id. az 1. ábrán az alsó panelt). PI. a 3 éves vállalatok ${ }^{5}$ évente átlagosan 20 százalékkal nőttek 2001-2015 között. Az 5. és 6. évet követően (életciklus-elemzések gyakran ezt a kort határozzák meg, amikor a vállalatok éretté válnak és kezdenek lelassulni) a növekedési ráta szignifikánsan csökken, 5 százalék alá, majd 10 éves kor felett a vállalatok már alig (max. 1-2 százalékos mértékig) növekednek. ${ }^{6}$

Bár a fiatal vállalatok rendszerint gyorsan növekednek, teljesítményük szóródik - ezt mutatja a növekedési ráta szóródása az 1. ábra alsó paneljén - és kilépési rátájuk is magas. A vállalatok egy szelekciós folyamaton mennek keresztül a belépést követően, a nem életképesek megszűnnek. A 3 éves vagy annál fiatalabb vállalatok között 10 százalék fölötti a megszűnők aránya. A kilépések hatása nem elhanyagolható az egyes korcsoportok növekedési rátájára sem - ezt mutatja a csak a továbbélő vállalatokra számított növekedési ráta és az összes, a következő évben kilépőket is tartalmazó vállalatokra számított növekedési ráta (az 1. ábra alsó panel két oszlopa) különbsége. Mindezen mutatók, így a kilépési ráta, annak növekedésre való hatása és a növekedési ráták szóródása is mérséklődik a korral.

\footnotetext{
${ }^{5} \mathrm{Az} 1$ éves vállalatok növekedési rátája definíció szerint 2. A 2 éves vállalatok növekedési rátája 1 fölött van, amit az ábrán nem mutatunk, aminek két oka van. Először is az ábra többi része így jobban látszik. Másfelől számításaink feltételezik, hogy a vállalatok minden évben az év egészében múködtek, ami biztos nem teljesül a belépők mindegyikére, akik éven belül bármikor beléphetnek. Ennek eredményeképpen a 2 évesek növekedési rátája felfelé torzított, miközben (középponti) súlyuk lefelé torzított. Végeredményben ez azt befolyásolja, hogy a növekedési ráta és a súly hogyan van hozzárendelve az első, illetve a második évhez. Mivel legtöbbször az 1-4 éves vállalatok csoportját egyben elemezzük, eredményeinkre ennek a problémának csak kicsi a hatása.

${ }^{6}$ Ez különbözik a munkahelyteremtés elemzéseinek eredményeitől, ahol általában azt találják, hogy az idősebb vállalatoknak negatív a hozzájárulása a foglalkoztatás növekedéséhez.
} 




Annak érdekében, hogy a fiatal vállalatok dinamizmusának aggregált jelentőségét értékelni tudjuk, a reál hozzáadott érték növekedését felbontottuk négy korcsoport hozzájárulására (2. ábra, felső panel). Azt találjuk, hogy az aggregált növekedéshez való hozzájárulás csökken a vállalat korával. Legszembetűnőbb, hogy a legfiatalabb korcsoport (1-4 évesek) alacsony súlya ellenére - a teljes Rva mindössze 7 százalékát állítják elő - a növekedés 70 százaléka nekik tulajdonítható. Ezzel szemben a 15 éves vagy annál idősebb vállalatok a teljes Rva nagyjából felét állítják elő, miközben növekedési hozzájárulásuk elhanyagolható. 


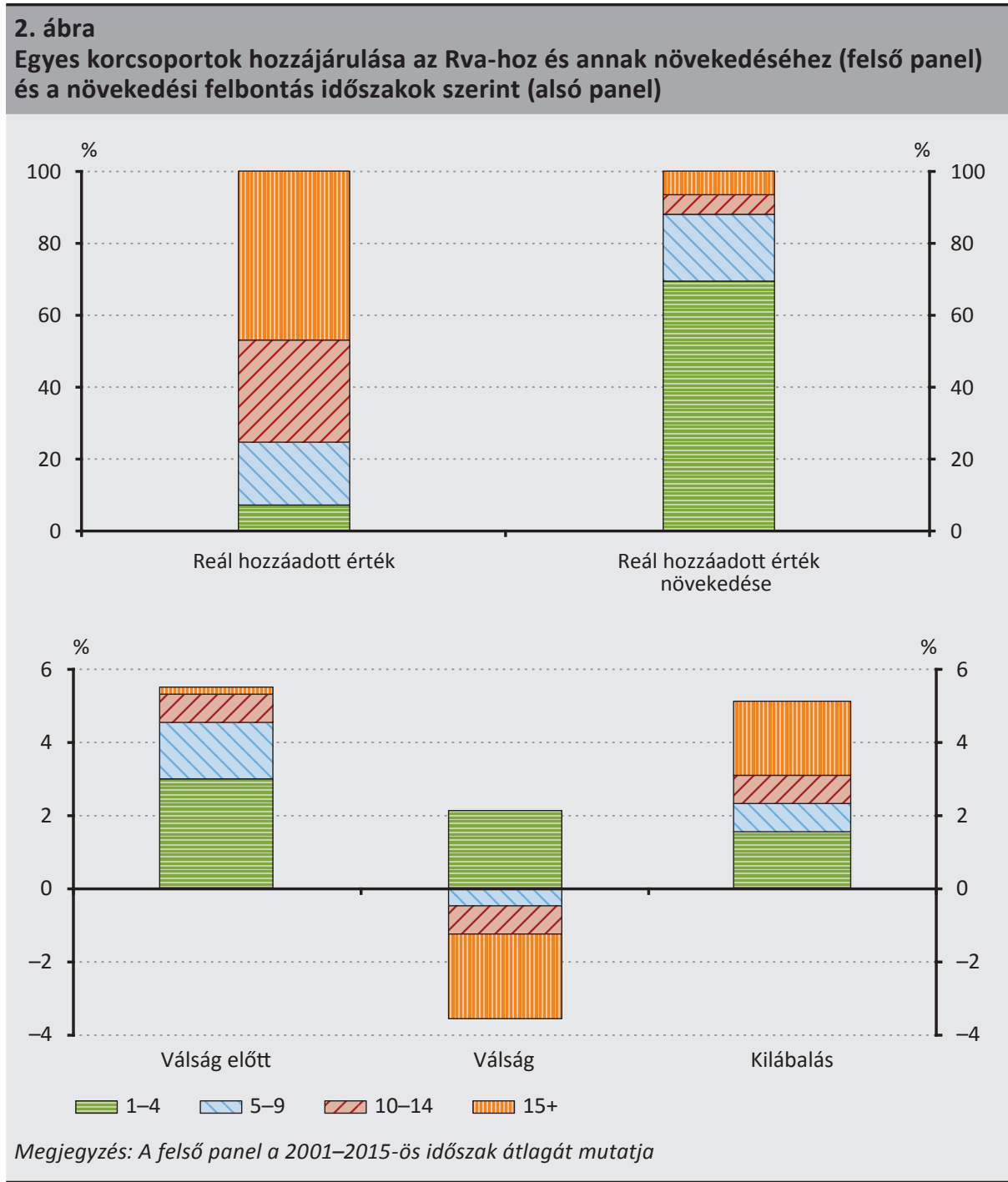

Ugyanakkor az egyes korcsoportok növekedési hozzájárulása változik az üzleti ciklussal (Id. 2. ábra, alsó panel). A fiatal vállalatok még a válság alatt is nőnek. Criscuolo et al. (2014) a foglalkoztatást vizsgálva hasonló eredményre jut. Kevesebb vállalat lép be és növekedési rátájuk alacsonyabb, mint a konjunktúra időszakában, de még mindig pozitív a növekedéshez való hozzájárulásuk. Ezzel szemben az idősebb vállalatok Rva-ja meredeken csökken a válság során, ami az aggregált növekedési rátát jócskán negatív tartományba viszi, a kilábalásnál viszont felugrik. Hatásuk az aggregált növekedésre fontossá válik a válság és a kilábalás alatt, ami nagy Rva-ból való részesedésük következménye és nem szükségképpen azért, mert ciklikusabban 
viselkednének.7 Érdekes módon a fiatal vállalatok teljesítménye 2013-2015-ben, a kilábalás idején sem javul, amiben fontos szerepe van a vállalatalapítási kedv tartós gyengeségének - a belépési ráta tovább csökkent ebben az időszakban.

A válság és a kilábalás során történtek részletesebb megértése érdekében az Rva növekedését másképp is felbontjuk (3. ábra). Ennek során különválasztjuk a bruttó szárakat: a továbbélő vállalatok teremtésére (a pozitív növekedésű vállalatok hozzájárulása) és rombolására (csökkenő Rva-jú vállalatok hozzájárulása), valamint a belépés teremtő és a kilépés romboló hatására. A válság kitörésekor a növekedési teljesítmény romlása mind a négy csatornán keresztül megfigyelhető. Több vállalat lép ki, a belépők hozzájárulása esik, és a továbbélő vállalatok teljesítménye is mérséklődik: a bruttó teremtés csökken, és a rombolás emelkedik, ami azt eredményezi, hogy a továbbélő́k nettó hatása negatív. Mind a belépés, mind a kilépés „akcelerátor” szerepet tölt be: a válság során nemcsak az aggregált lassuláshoz járulnak hozzá, de a bruttó teremtésben, ill. rombolásban való részesedésük is csökken (belépés esetén), ill. nő (kilépés esetén). Az új belépők bruttó teremtésben való részesedése 6,6 százalékról 4,9 százalékra csökken a válság során, míg a kilépések bruttó rombolásból való részesedése 7 százalékról 7,9 százalékra emelkedik.

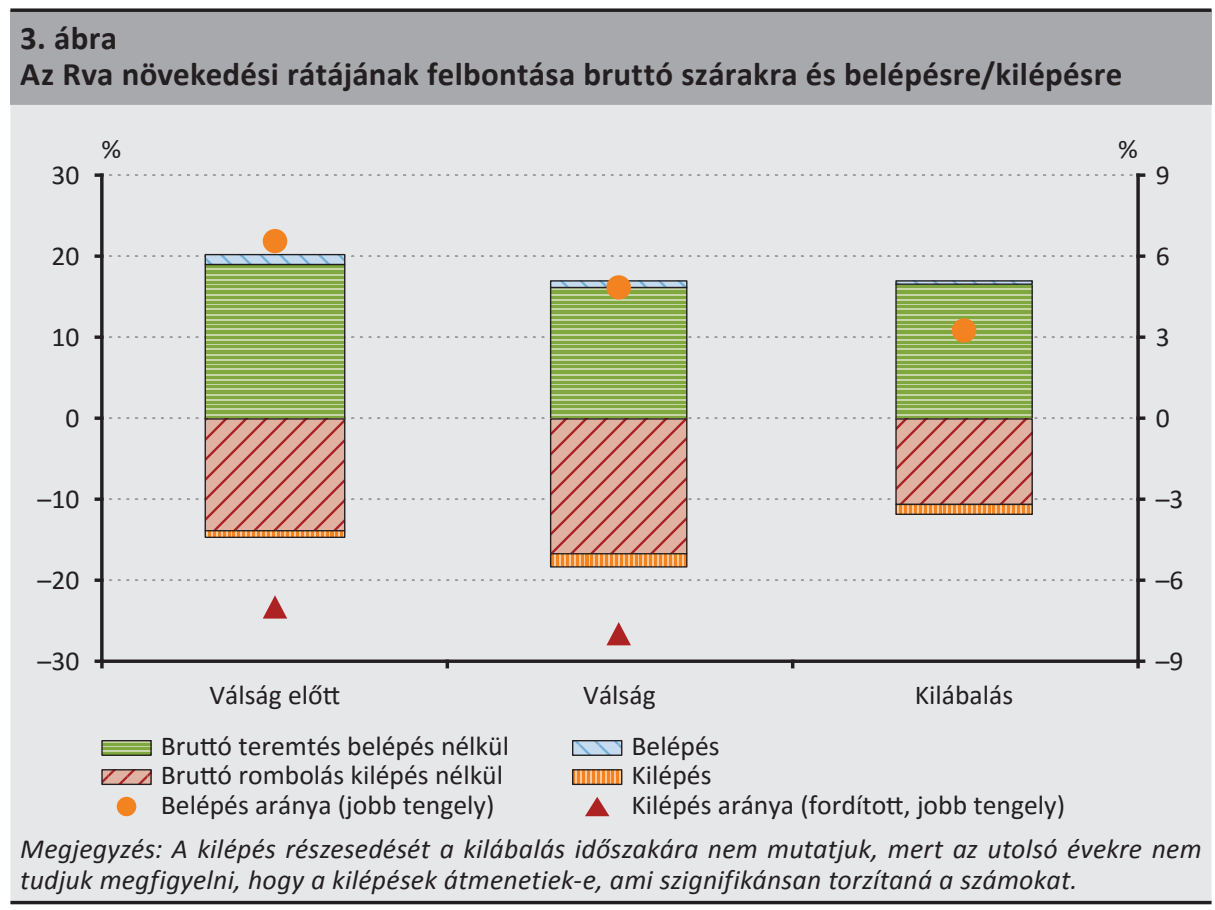

${ }^{7}$ A vizsgált időszakban a vállalatok fokozatos öregedése figyelhető meg, ami a válság miatt felgyorsult. Az öregedés miatt növekszik az idősebb vállalatok súlya az Rva-ban. Az idősebb vállalatok visszapattanása a kilábalás során azonban csak részben magyarázható növekvő súlyukkal. Az egyszerúség kedvéért az Rva növekedését nem bontjuk fel a súlyok, ill. a növekedés hatására. 
A kilábalás időszaka, ahelyett, hogy a válság tükörképe lenne, sajátos jellemzőkkel bír. A növekedési teljesítmény javulása a kevesebb rombolásnak köszönhető, de sem a vállalatalapítási, sem a növekedési kedv (vagy lehetőség) nem javul. A továbbélő vállalatok között kevesebb vállalat zsugorodik, vagy a csökkenés mértéke kisebb; a növekvő vállalatok hozzájárulása viszont nem változik. A kilábalás egy másik megkülönböztető és riasztó jellemzője a belépők hozzájárulásának további mérséklődése. Ezt a mérséklődést a hozzájárulás mértékében és a bruttó teremtés arányában is megfigyeljük - ez utóbbi 3,3 százalékra esik, ami a válság előtti arány mindössze fele. Ez a viselkedés éles ellentétben áll a kilépésekkel: azok (negativ) hozzájárulása a teljes növekedéshez - ahogy várható is - csökken a kilábalás során. A kilépések bruttó rombolásban való relatív jelentősége adatproblémák miatt nem ítélhető meg erre az időszakra. ${ }^{8}$

Összességében úgy tűnik, hogy a kilépések viselkedése kontraciklikus, hatásuk felerősödik visszaesés idején. A kontraciklikus kilépés szerepének megítélése azonban nem egyértelmű. Egyfelől a kilépések miatt termelő kapacitások tűnnek el átmenetileg, vagy akár véglegesen is, amennyiben a termelési tényezők reallokációja korlátozott. Másfelől a recesszióknak lehet egy tisztító hatása a kilépéseken keresztül, amikor a legkevésbé termelékeny vállalatok kiszorulnak a piacról. Az, hogy a Nagy Recesszió során mennyire múködött ez a tisztító hatás, jövőbeli kutatások tárgya lehet.

Ami a belépéseket illeti, azt várjuk, hogy azok prociklikusak. A belépők a recesszió során valóban mutatják a prociklikusság jeleit, de viselkedésük a kilábalás során nem szokványos. A belépők és általában a fiatal vállalatok hozzájárulása lefelé ível a válság kezdete óta. A belépési ráta visszaesését sok országban megfigyelték a Nagy Recesszió során, melynek mértéke és tartóssága néhány országban historikusan is kiugrónak tekinthető ${ }^{9}$. Magyarországon a vállalatalapítási kedv tartósan visszaesett, a belépési ráta még 8 évvel a válság kitörése után is csökkent. Az alacsony belépési ráta hosszú távon árt a növekedésnek, mivel egy adott évben alacsony vállalatalapítási kedv nemcsak abban az évben mérsékeli a növekedést, hanem a rákövetkezőkben is, hiszen a fiatal, dinamikus cégek aránya is visszaesik. Emiatt a belépések visszaesése tartós lassulást okoz a kibocsátásban. A belépések (és kilépések) fontosságát és potenciális szerepüket a kilábalás elhúzódásában nemcsak

\footnotetext{
${ }^{8}$ A kilábalási időszakhoz tartozó kilépési számok felfelé torzítottak. Általában sok olyan vállalat van a magyar gazdaságban, amely átmenetileg „kilép” (nem jelent beszámolót), majd néhány évvel később újra elkezd müködni és pénzügyi jelentéseket készíteni. Mintánk vége felé a két típusú kilépés megkülönböztetése lehetetlenné válik. Néhány véglegesnek bekategorizált kilépésről ki fog derülni, hogy csak átmeneti, így a kilépés mért hatása a kilábalási periódusban felfelé torzított. A kilépések szerepe még így is csökken a kilábalás időszakában, ami még hangsúlyosabb lenne, ha a kilépést megfelelően tudnánk mérni. Emiatt a probléma miatt azonban a kilépések rombolásban való részesedését nem mutatjuk az ábrán.

${ }^{9}$ Az USA esetében a jelenséget Gomis - Khatiwada (2017), Gourio et al. (2016) és Clementi et al. (2017) is dokumentálja.
} 
empirikus tanulmányok ismerték fel, hanem elméleti modellekbe is beépítették (Clementi - Palazzo 2016 és Clementi et al. 2017). ${ }^{10}$

Ahogy megmutattuk, a fiatal vállalatok dinamikusak és kicsik, így adódik a kérdés, hogy a méret vagy a kor a fontosabb a növekedés szempontjából. Haltiwanger és szerzőtársai (2006) megmutatják foglalkoztatási adatokon, hogy a kisméretű vállalatoknak jellemzően nagyobb a hozzájárulásuk a munkahelyteremtéshez, de ha korra kontrollálunk, akkor a hatás eltűnik. Úgy tűnik tehát, hogy a pozitív korreláció a méret és a kor között annak köszönhető, hogy a kisméretű vállalatok jellemzően fiatalabbak. Ugyanezt az eredményt kapja magyar adatokon Benk - Morvay - Teleg$d y$ (2018). Hasonló vizsgálatot végzünk mi is, ahol az Rva-növekedést regresszáljuk a vállalatméret és a kor dummyjain, miközben kortollálunk az év és ágazati fix hatásokra. Az eredmények részben eltérnek a foglalkoztatásra vonatkozó megállapításoktól, azt találjuk ugyanis, hogy a nagyobb vállalatok korra való kontroll nélkül is gyorsabban nőnek. A mikrovállalatok és a többi vállalat között a legnagyobb az eltérés (4. ábra). A kis-, közepes és nagyvállalati csoport között megfigyelt különbségek nem szignifikánsak. Ha a korra is kontrollálunk, azaz azonos korú vállalatokat hasonlítunk össze, akkor - ahogy vártuk - az átlagos eltérések tovább emelkednek (a becsült együtthatók duplázódnak), a kisebb vállalatok kárára.

A válság során (alsó panel a 4. ábrán) a mikrovállalatok relatív teljesítménye enyhén romlott, de a kilábalás időszakában ez megfordult, különösen a nagy- és középvállalatokkal összehasonlítva.

A kor hatására vonatkozó becslési eredmények megerősítik a korábbi megállapításainkat, a növekedési ráták meredeken csökkennek a korral (5. ábra). A méretre történő kontrollálásnak alig van hatása az eredményekre. Összességében úgy túnik, hogy a kor jelentősége nagyobb a méretnél. A különböző modellek parciális $\mathrm{R}^{2}$-einek összehasonlítása alapján ugyanerre a következtetésre juthatunk (ezeket az eredményeket nem mutatjuk be).

\footnotetext{
${ }^{10}$ A belépési ráták csökkenését és annak hatását a vállalati beruházásokra Bauer-Endrész (2017) tanulmánya mutatja be.
} 


\section{4. ábra \\ Rva-növekedés méret szerint \\ (Az együtthatók az Rva növekedésének méretre és korra való regressziójából becsülve, mikrovállatok=0)}


Korra kontrollálva

Pontbecslés Alsó határ _ Felső határ

Megjegyzés: Átlagos (t és $t-1$ között) Rva-értékekkel súlyozott lineáris regressziós együtthatók, a mikrovállalatok képezik a kontrollcsoportot, év és 2 jegyú ágazati dummykat szerepeltetünk. Az alsó és felső határok a 95 százalékos konfidencia-intervallum határait jelentik. 


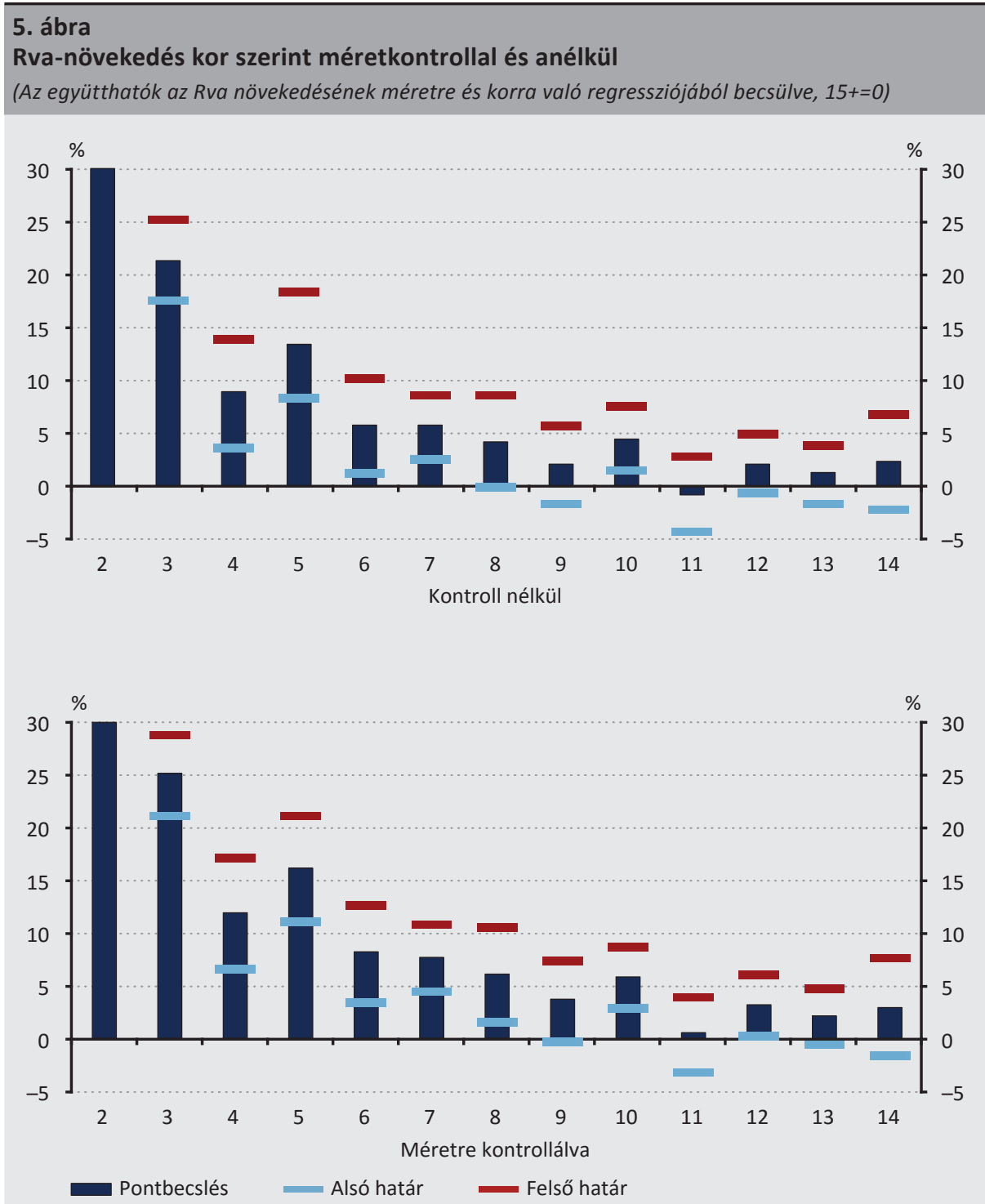

Megjegyzés: Átlagos (t és t-1 között) Rva-értékekkel súlyozott lineáris regressziós együtthatók, a 15+ korcsoport képezi a kontrollcsoportot, év és 2 jegyü ágazati dummykat szerepeltetünk. Az alsó és felső határok a 95 százalékos konfidencia-intervallum határait jelentik. A függőleges tengely 30 százaléknál csonkított. 


\section{Termelékenység és kor}

Ebben a részben a termelékenység és a kor közötti kapcsolatot vizsgáljuk, valamint a belépés és kilépés hatását a termelékenységre. A termelékenységet a vállalatok logaritmusban kifejezett munkatermelékenységével mérjük, azaz az egy alkalmazottra jutó reál hozzáadott érték logaritmusával. ${ }^{11}$ Az aggregált termelékenység a létszámmal súlyozott átlaga a vállalati szintű (log) termelékenységnek. Így az aggregált termelékenységet úgy is értelmezhetjük, mint a vállalati szintű termelékenységek geometriai átlagát. A munkatermelékenységnek megvan az az előnye, hogy megfigyelhető, szemben a teljes- (vagy sok-) tényezős termelékenységgel (TFP vagy MFP), ami a termelékenység közvetlenül nem megfigyelhető mutatója. A termelékenység szintje pozitívan korrelál a korral (6. ábra). Míg a belépő (1 éves) vállalatok munkatermelékenysége érdemben alacsonyabb az idősebbekénél, a termelékenység növekedése 10 éves kor körül lelassul.

A válság nem változtatta meg szignifikánsan a kor és termelékenység közötti kapcsolatot. Megfigyelhetjük, hogy a belépő vállalatok termelékenysége magasabb a kilábalási időszakban (2013-2015), mint korábban. Ez összefügghet az alacsonyabb belépési ráta miatti önszelekcióval. Ez a jelenség a belépők némileg nagyobb méretében is megmutatkozhat (ezt itt nem mutatjuk).



${ }^{11}$ Az alkalmazottak száma adatbázisunkban teljes munkaidős egyenértékes, így az egy főre jutó munkaórák számának változását korrigálja. 
Ahogy láttuk, a belépő vállalatok alacsonyabb termelékenységűek, mint a már létező idősebb vállalatok, így a belépés azonnali hatása az aggregált termelékenységre negatív. Nem ez a helyzet a kilépések esetében (7. ábra, felső panel). A kilépő vállalatok (akik a következő évben már nem léteznek) mindig alacsonyabb termelékenységűek, mint a létező vállalatok átlaga ugyanabban a korcsoportban. Így a kilépés hatása a termelékenységre mindig pozitív. De a kilépő vállalatok termelékenysége is növekszik a korral. Így a legalább 3 éves (és rendszerint, bár nem mindig, a 2 éves vállalatok is) magasabb termelékenységűek átlagosan, mint a belépő vállalatok. Ez azt jelenti, hogy a nettó belépés hatása a termelékenységre akár negatív is lehet, ha a legalább 3 éves kilépők súlya elég magas ahhoz, hogy ellensúlyozza az 1 és 2 éves kilépők alacsonyabb termelékenységét.

Mivel a kilépés minden korcsoport termelékenységét képes emelni, ezért természetes a kérdés, hogy a korral emelkedő termelékenységi szint mennyiben köszönhető a kilépéseknek. A kérdés vizsgálata céljából kiszámítottuk a továbbélők átlagos termelékenységét, azaz azon vállalatokét, amelyeknek van az előző és a következő évben is munkatermelékenysége. Így a ki- és belépés nem befolyásolja a kor-termelékenység kapcsolatot ebben az esetben. ${ }^{12}$ Eredményeink szerint a termelékenység kor szerinti emelkedése igen hasonló ahhoz az esethez, amikor az összes vállalatot figyelembe vesszük, csak a görbe tolódik felfelé (7. ábra, alsó panel). Ez azt jelenti, hogy a termelékenység kor szerinti emelkedését nem az alacsonyabb termelékenységű vállalatok kilépése okozza. ${ }^{13}$

A termelékenység méret szerinti alakulását is megvizsgáljuk. Azt találjuk, hogy a nagyobb vállalatok termelékenysége magasabb, ami összhangban van a Magyarországra és számos más országra is korábban már feltárt eredményekkel (ld. pl. OECD 2017 a nemzetközi eredmények, vagy MNB 2015 Magyarország esetében). Ez nem meglepő, tekintve, hogy a nagyobb méretű vállalatok kihasználhatják a mérethozadék előnyeit. Mivel a kor és a méret pozitivan korrelál, olyan regressziót is futtattunk, ahol a korra kontrollálunk (ezenkívül év és 2 számjegyú ágazati fix hatásokra is). Ezzel kiszűrjük a kor méreten keresztüli hatását a termelékenységre. Eredményeink szerint a nagyobb vállalatok továbbra is termelékenyebbek (8. ábra, felső panel). Ez azt jelenti, hogy két azonos korú vállalatot összehasonlítva a nagyobbnak átlagosan magasabb a termelékenysége. Megjegyezzük, hogy a korra való kontrollnak kisebb a jelentősége a termelékenység esetében, mint a hozzáadott érték növekedése esetében (az együtthatók kisebb mértékben változnak).

${ }^{12} \mathrm{Az}$ általánosabb értelemben vett belépés az 1 évesnél idősebb vállalatok esetében is lehetséges, mivel a log-munkatermelékenység hiányzó értéket vesz fel nulla létszám vagy nulla hozzáadott érték esetén.

${ }^{13}$ A termelékenységnövekedés forrásainak részletesebb elemzése a reallokáció termelékenységre való hatásának vizsgálatát igényelné, amely azonban nem tárgya jelen tanulmánynak. 


\section{7. ábra \\ A munkatermelékenység átlaga az összes és a kilépő vállalatokra, ill. a továbbélő vállalatokra kor szerint \\ (Foglalkoztatással súlyozott log-munkatermelékenység)}
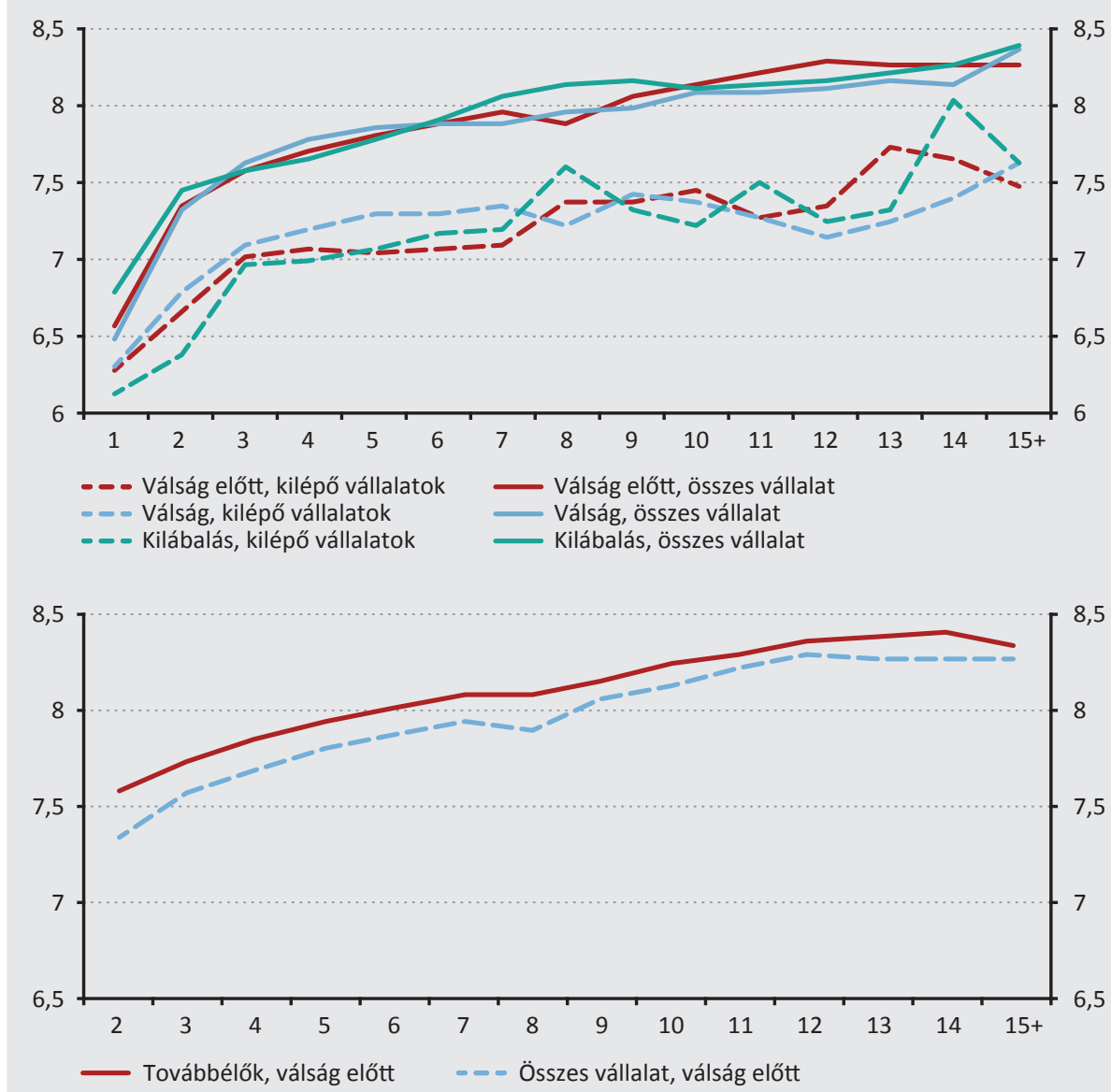

Megjegyzés: A továbbélök olyan vállalatok, amelyeknek létezik log-munkatermelékenysége az elöző és a következö évben is. Ez azt jelenti, hogy sem belépök nem lehetnek, sem pedig nem léphetnek ki a következő évben.

Regresszió segítségével azt is ellenőriztük, hogy megmarad-e a pozitív kapcsolat a kor és a termelékenység között, ha méretre kontrollálunk (továbbá év és 2 számjegyű ágazati fix hatásokra). Az eredmények azt mutatják, hogy az együtthatók csak csekély mértékben változnak, így a termelékenység továbbra is emelkedik a korral (8. ábra, alsó panel). 


\section{8. ábra}

Munkatermelékenység méret (felső panel) és kor (alsó panel) szerint

(Az együtthatók a log-munkatermelékenység méretre és korra való regressziójából becsülve, mikrovállalatok=0, ill. $15+=0$ )


Megjegyzés: Foglalkoztatottsággal súlyozott lineáris regressziós együtthatók, a mikrovállalatok csoportja a kontrollcsoport a méret, a 15+ éves vállalatok csoportja a kontrollcsoport a kor esetében, év és 2 számjegyü ágazati dummykat szerepeltetünk. Az alsó és felső határok a 95 százalékos konfidencia-intervallum határait jelentik.

Megvizsgáltuk azt is, hogy a méret vagy a kor magyarázza-e jobban a termelékenység varianciáját. Az eredmények szerint (amelyek a modellek parciális $\mathrm{R}^{2}$-ein alapulnak) a vállalat mérete fontosabb meghatározója a termelékenységnek, mint a kor. 


\section{Exportnövekedés és kor}

Az exportálás alapvető indikátora a vállalati teljesítménynek: általában a termelékenyebb vállalatok képesek exportálni. Az export aggregált szempontból is fontos, hiszen Magyarország rendkívül nyitott gazdaság, és a gazdasági növekedés fő forrása az export. Ezért az alábbiakban a vállalatok exportaktivitását és annak korral való változását is megvizsgáljuk. A vállalati szintű export növekedését ugyanúgy számítjuk, mint a hozzáadott érték esetében, az ún. középponti növekedéssel. Ebben a fejezetben a belépést és kilépést újradefiniáljuk: itt az exportpiacra való belépést, ill. kilépést értjük alatta.

A kor és az exportnövekedés közötti kapcsolat nagyon hasonló a hozzáadott érték növekedéséhez (9. ábra). A fiatal vállalatok sokkal gyorsabban növekednek, mint az idősebb vállalatok, és a növekedési ráta lassabban mérséklődik idősebb korban. A fő különbség az, hogy az export esetében az idős (több mint 10 éves) vállalatok is pozitív növekedést mutatnak, szemben a hozzáadott érték növekedésével, ahol az nagyon közel volt a nullához. Ezt az a tény magyarázhatja, hogy számos vállalat csak későbbi életszakaszban képes belépni az exportpiacokra, amikor elérik a szükséges termelékenységet és versenyképességet. Az exportpiacok puszta mérete és növekedése és az exportálás sajátosságai szintén arra késztethetik a vállalatokat, hogy innovatívak és dinamikusak maradjanak idősebb korukban is.

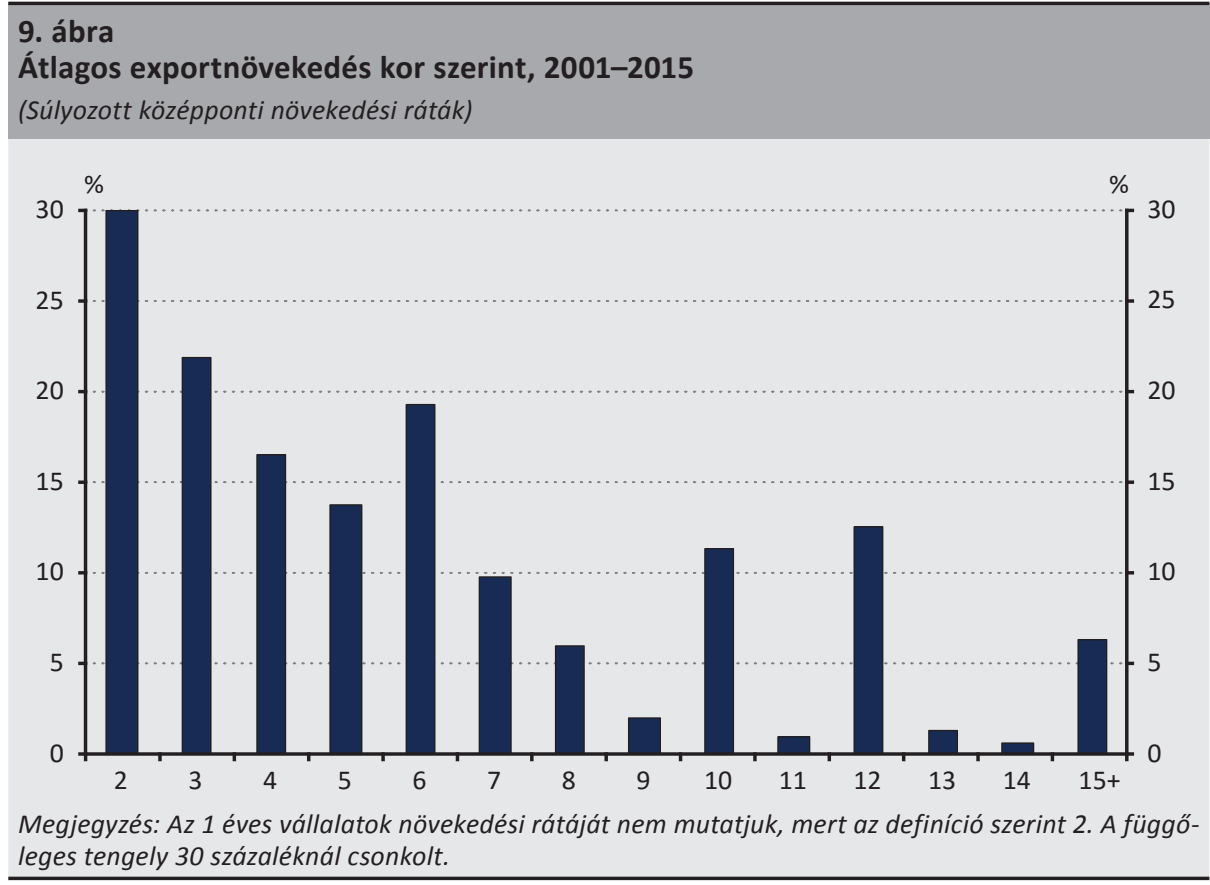


A különböző korcsoportok jelentősége az aggregált export növekedésében nemcsak a növekedési rátájuktól, hanem súlyuktól is függ. Ezért az exportnövekedést (is) felbontjuk az egyes korcsoportok növekedési hozzájárulására. Az eredmények szerint a fiatal vállalatoknak szignifikánsan kisebb szerepe van az exportnövekedésben, mint a hozzáadott érték növekedésében (10. ábra, felső panel). Az idősebb vállalatok még a válság előtt is domináltak, amikor pedig az átlagos vállalati kor alacsonyabb volt, mint később. A válság alatt nemcsak a legfiatalabb vállalatok hozzájárulása pozitiv, hanem a legidősebbeké is. A válságot követően a legfiatalabb vállalatok hozzájárulása marginálisnak tekinthető. $A z$, hogy az idősebb vállalatok fontosabbak az export növekedésében, mint a hozzáadott érték növekedésében, szorosan összefügg a fent bemutatott összefüggéssel, miszerint az idősebb vállalatoknak is pozitív az exportnövekedése. Azt is érdemes megjegyeznünk, hogy eredményünk nem az idősebb vállalatok aránytalanul nagy súlyának következménye, mivel az exportsúlyok nagyon hasonlóak a hozzáadott érték súlyaihoz (ezt itt nem mutatjuk be).

A kor szerepén túl az extenzív határ, azaz a belépés és kilépés fontosságát is be szeretnénk mutatni az exportnövekedésben. Ennek céljából az aggregált export növekedését négy csoport hozzájárulására bontottuk fel. Az első csoportban (bruttó teremtés belépés nélkül) olyan vállalatok vannak, amelyek az előző évben exportáltak, emiatt nem lehetnek belépők, és pozitív növekedést mutatnak. A második csoportban (bruttó rombolás kilépés nélkül) lévő vállalatok exportálnak az aktuális évben (így nem kilépők), de negatív a növekedési rátájuk. A harmadik és negyedik csoport a belépő, ill. kilépő vállalatok csoportja. A 10. ábra (alsó panel) mutatja a felbontást és a belépők részesedését a bruttó teremtésből. ${ }^{14} A$ leglényegesebb következtetés, hogy a belépés hozzájárulása érdemben csökkent a válságot követően, mind abszolút mértékben, mind a bruttó teremtéshez viszonyítva. Egy másik megfigyelés, hogy az exportnövekedés lassulása a válság alatt (2008-2012) elsősorban a továbbélő vállalatok kisebb bruttó teremtésének és nagyobb bruttó rombolásának köszönhető, míg a belépés és kilépés hozzájárulása kevésbé változott. A kilábalás mögött a kisebb bruttó rombolás áll, beleértve a kilépés csökkenő (negatív) hozzájárulását. ${ }^{15} \mathrm{~A}$ kilábalásban, hasonlóan a hozzáadott érték növekedéséhez, a bruttó teremtés nem játszik szerepet, még akkor sem, ha figyelmen kívül hagyjuk a mérséklődő belépési rátát.

Ezután megvizsgáljuk az exportnövekedést méret szerint is (a magyar exportaktivitást vállalati méret szerint vizsgálta az MNB 2017, ill. az export növekedésének és a méretnek a kapcsolatát Franciaországban Berthou - Vicard 2015). Még korra való kontrollálás mellett is a nagyobb vállalatoknak magasabb az exportnövekedési rátája (11. ábra, felső panel). Érdemes azt is megjegyezni, hogy a méret miatti

\footnotetext{
${ }^{14}$ Lényeges, hogy a belépők hozzájárulását a bruttó teremtés arányában mutatjuk, és nem a nettó belépést a teljes növekedés arányában. A nettó belépés és még a teljes növekedés is lehet negatív, így a részesedés értelmetlen. A bruttó teremtés és a belépés viszont mindig pozitiv és a belépés része a bruttó teremtésnek, így ebben az esetben van értelme a részesedést nézni.

${ }^{15}$ A kilépés csökkenő fontossága részben az alacsonyabb belépési rátához kapcsolódhat, mivel a fiatal vállalatoknak magas a kilépési rátája.
} 
10. ábra

Az exportnövekedés felbontása korcsoportok szerint (felső panel) ill. növekvő, zsugorodó, belépő és kilépő vállalatokra (alsó panel)

(Súlyozott növekedési ráták)






\section{1. ábra}

Exportnövekedés méret szerint (felső panel) és kor szerint (alsó panel)

(Az együtthatók az exportnövekedés méretre és korral való regressziójából becsülve, mikrovállalat=0, ill. $15+=0)$
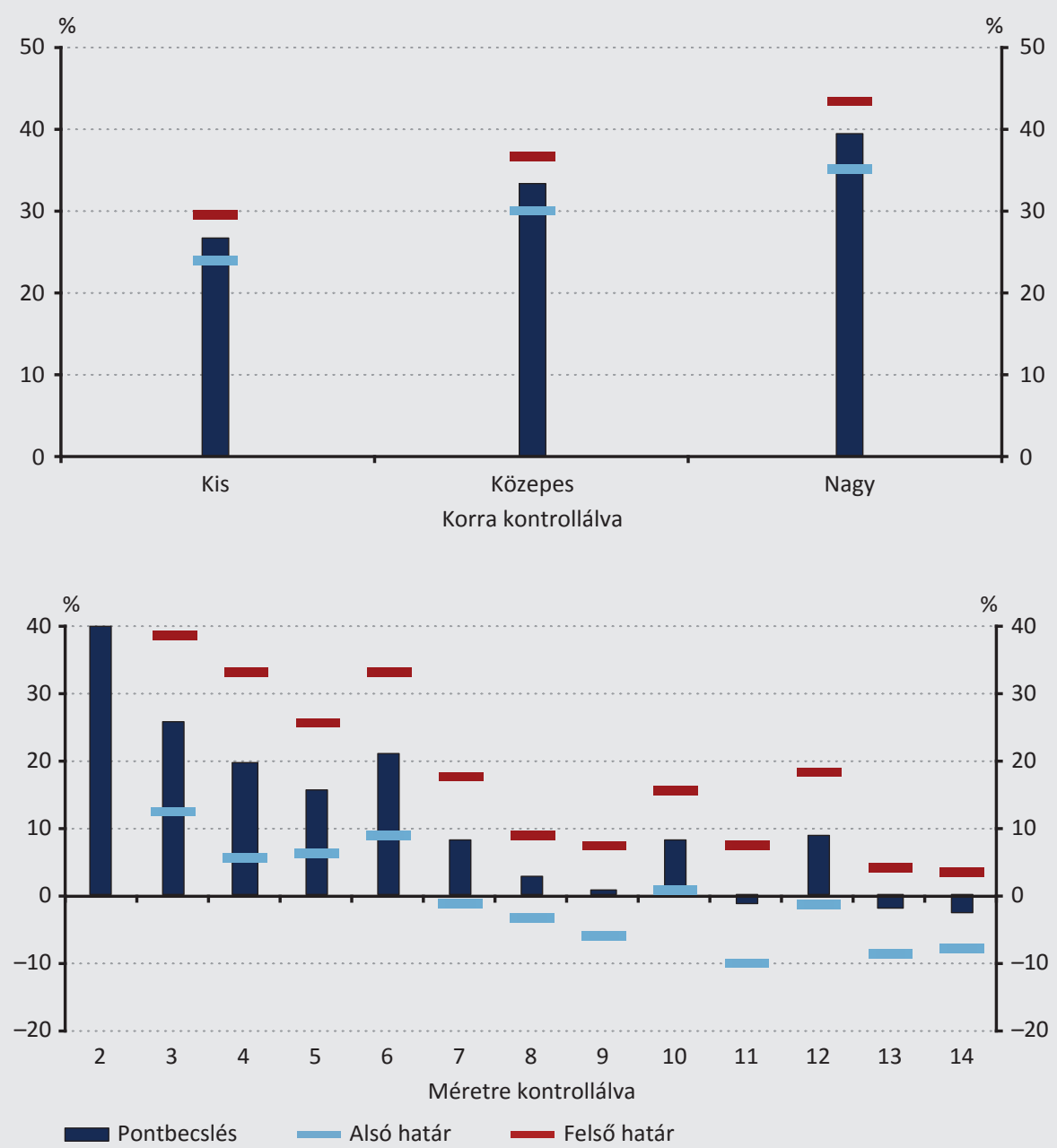

Megjegyzés: Átlagos (t ill. t-1 időszaki) exporttal súlyozott lineáris regressziós együtthatók, a méret esetében a mikrovállalatok képezik a kontrollcsoportot, a kor esetében a 15+ éves vállalatok, év és 2 számjegyü ágazati dummykat szerepeltetünk. Az alsó és a felső határok a 95 százalékos konfidencia-intervallum határait jelentik.

különbségek (pl. mikro- és kisvállalatok között), sokkal nagyobbak, mint a hozzáadott érték növekedésének esetében.

Megvizsgáltuk azt is, hogy a kor és exportnövekedés közötti kapcsolat megmarad-e, ha kontrollálunk a vállalati méretre. Az eredmények szerint (11. ábra, alsó panel) az exportdinamika korral csökken, még méretre való kontroll után is. Azt a kérdést is 
tanulmányoztuk, hogy a kor vagy a méret fontosabb-e az exportnövekedés magyarázatában. Azt találtuk (parciális $\mathrm{R}^{2}$-ek alapján), hogy a kor fontosabb, mint a méret, de a méret relatív fontossága magasabb, mint a hozzáadott érték esetében.

\section{Hitelezés és kor}

A vállalati életciklus egyes szakaszaiban változnak a hitelezést befolyásoló keresleti és kínálati tényezők. Emiatt szoros kapcsolatot várunk a banki hitelezés és a vállalatok kora között ${ }^{16}$. A fiatal vállalatok jellemzően gyorsan növekednek és ennek megfelelően magas a finanszírozási igényük. Mivel azonban fiatalok és kicsik, kockázatosak (magas a csődráta, a megszűnők aránya), és gyakran nincs fedezetképes eszközük, hitelképességük alacsony, a banki hitelkínálat korlátozott. Ahogy növekednek, jövedelmezőbbekké és kevésbé kockázatossá válnak, ami növeli a bankok finanszírozási hajlandóságát. Ahogy tovább öregszenek, a növekedésük lelassul, csökkentve finanszírozási igényüket, miközben egyre inkább képesek elegendő belső forrást generálni. Összességében fordított $U$ alakú kapcsolatot várnánk a kor ${ }^{17}$ és a bankhitelek felhasználása között, ahol a kínálat főként a felfelé ívelő részen játszik szerepet.

A banki hitelezés időbeli alakulása is érdeklődésre tart számot, mivel a válság megváltoztatta a banki kínálatot, aminek hatása lehetett az aggregált növekedésre.

A bankhitel és a vállalati kor kapcsolatának vizsgálata eltér a korábbi elemzésektól. A hitelinformációs rendszerben a vizsgált időszak jelentős részében csak a hitelszerződések értékéről szerepel információ, a mindenkori fennálló állományokról nem. Emiatt a hitel értéke és annak növekedési rátája helyett a vállalatok bankkapcsolatának valószínűségét elemezzük, megkülönböztetve az új hitel felvételének, ill. a hitel meglétének valószínűségét. Még ebben az esetben is a teljes lefedettség csak 2005-től biztosított, így a vizsgált időszak a 2005-2015 közötti évekre rövidült le. Csak bizonyos intézményeket (bankok, külföldi bankfiókok és lízingtársaságok) vizsgálunk, és csak bizonyos típusú szerződéseket (hitelek, hitelkeretek, lízing, követelésvásárlás). Ugyanakkor az eredmények minőségileg nem különböznek, ha speciális pénzügyi intézményeket és takarékszövetkezeteket vagy egyéb típusú szerződéseket (garancia, stb.) is figyelembe veszünk. Utóbbi eredményeket azonban nem mutatjuk be.

Az új hitel felvételének, ill. a hitellel való rendelkezésnek a valószínúsége pozitívan korrelál a vállalat korával (lásd 12. ábra). Minél idősebb egy vállalat, annál valószínúbb, hogy van hitele, vagy új hitelt vesz fel. A valószínűség folyamatosan növekszik egészen 5-6 éves korig, amit valószínúleg a kínálat változása okoz. Ahogy

\footnotetext{
${ }^{16}$ Az életciklus és a vállalati tőkestruktúrára vonatkozó döntések közötti kapcsolattal foglalkozik pl. Castro et al. (2014) és Bulan és Yan (2010).

${ }^{17} \mathrm{~A}$ kort gyakran az életciklus egyes fázisainak proxyjaként használják.
} 
12. ábra

Új hitel felvételének (felső panel), ill. hitellel való rendelkezésnek (alsó panel) kor szerinti valószínúsége időszakonként
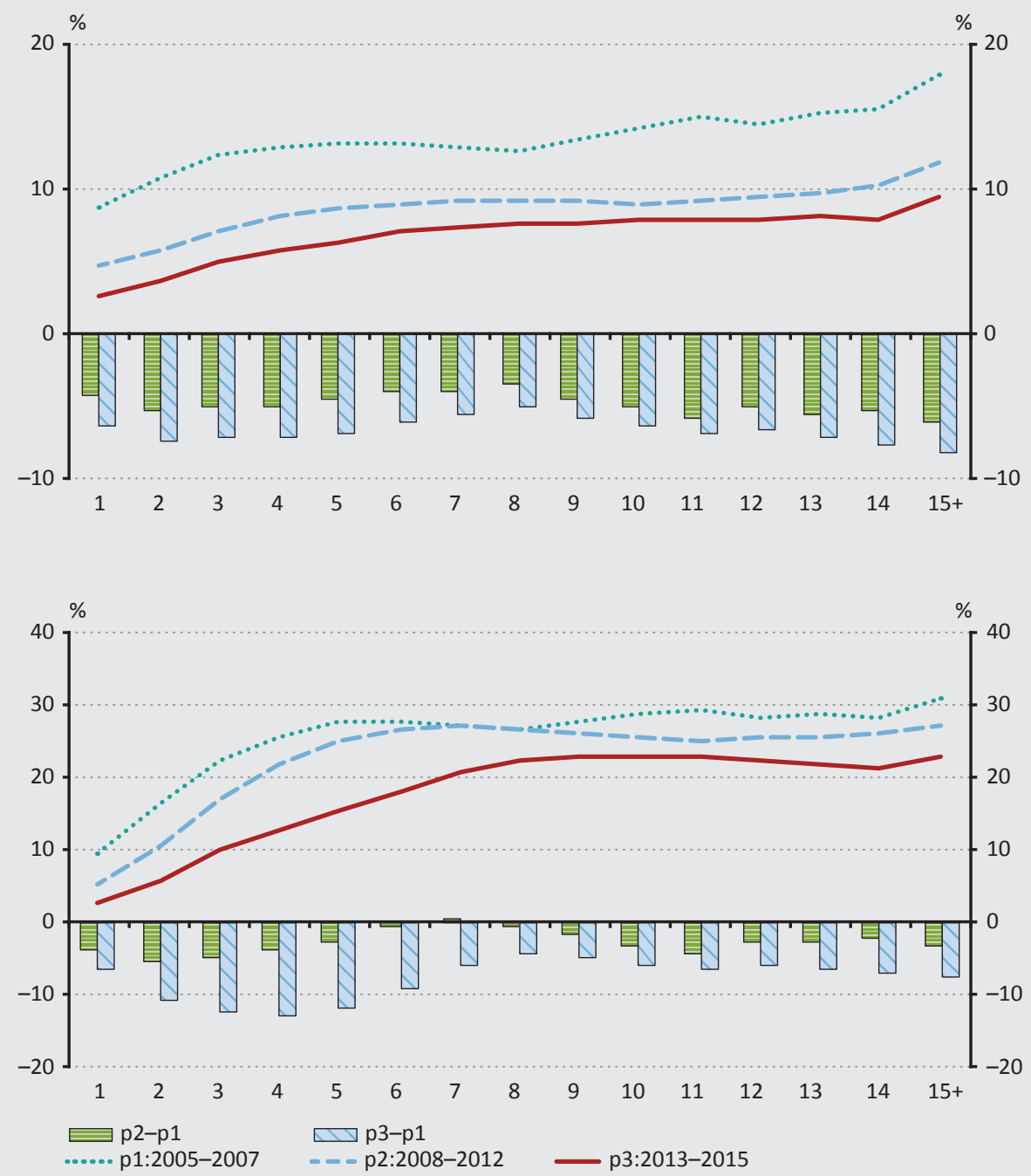

Megjegyzés: Súlyozatlan valószínüségek. p1, p2 és p3 a 2005-2007, 2008-2012, ill. 2013-2015-ös idöszakot, míg p2-p1 és p3-p1 az ezen időszakok közötti különbségeket jelöli.

azt már korábban láttuk, ez az a kor, ahol a növekedés elkezd lelassulni (1. ábra, alsó panel). A válság előtt az érett és idős vállalatok (mindazok, amelyek 5 évesnél idősebbek) közel 30 százaléka rendelkezett bankhitellel, míg körülbelül 15 százalékuk vett fel hitelt évenként, átlagosan. A válság kitörését követően hatalmas visszaesés van a bankhitelek használatában. A valószínúségek még a kilábalás alatt is csökkennek. A legfiatalabb és legöregebb cégek a leginkább érintettek. Az, hogy ennek mennyiben kínálati és mennyiben keresleti okai vannak, további kutatást igényel. 
A kor és a banki hitelfelvétel közötti kapcsolat változik némileg amikor regressziót futtatunk egyszerű, átlagos valószínűségek számítása helyett, viszont követi a várt fordított U alakot (13. ábra). Még inkább így van ez, amikor a vállalat méretére is kontrollálunk.


Megjegyzés: A bankhitellel rendelkezés lineáris valószínüségi modelljének becslése súlyozatlan regreszszióval. A kontrollcsoport a 15+ évesek csoportja. Év és 2 számjegyü ágazati dummykat szerepeltetünk. Az alsó és felső határok a 95 százalékos konfidencia-intervallum határait jelentik. 
A bankhitel használatának valószínúsége a vállalati mérettel is emelkedik. Ez a korreláció nem nagyon változik akkor sem, ha ugyanolyan korú vállalatokat hasonlítunk össze (azaz a korra is kontrollálunk). Láthatólag a méretnek nagy hatása van a hitelfelvételre. A mikrovállalatoknak a legnagyobb a hátrányuk, annak valószínúsége, hogy hitellel rendelkeznek, 30-40 százalékponttal marad el a nagyobb vállalatokétól. A közép- és nagyvállalati kör bankhitel-használata nagyon hasonló (14. ábra).

\section{4. ábra}

A vállalat mért hatása az új hitel felvételének (felső panel), ill. a hitellel rendelkezésnek a valószínúségére (alsó panel)

(Regressziós együtthatók, mikrovállalatok=0)
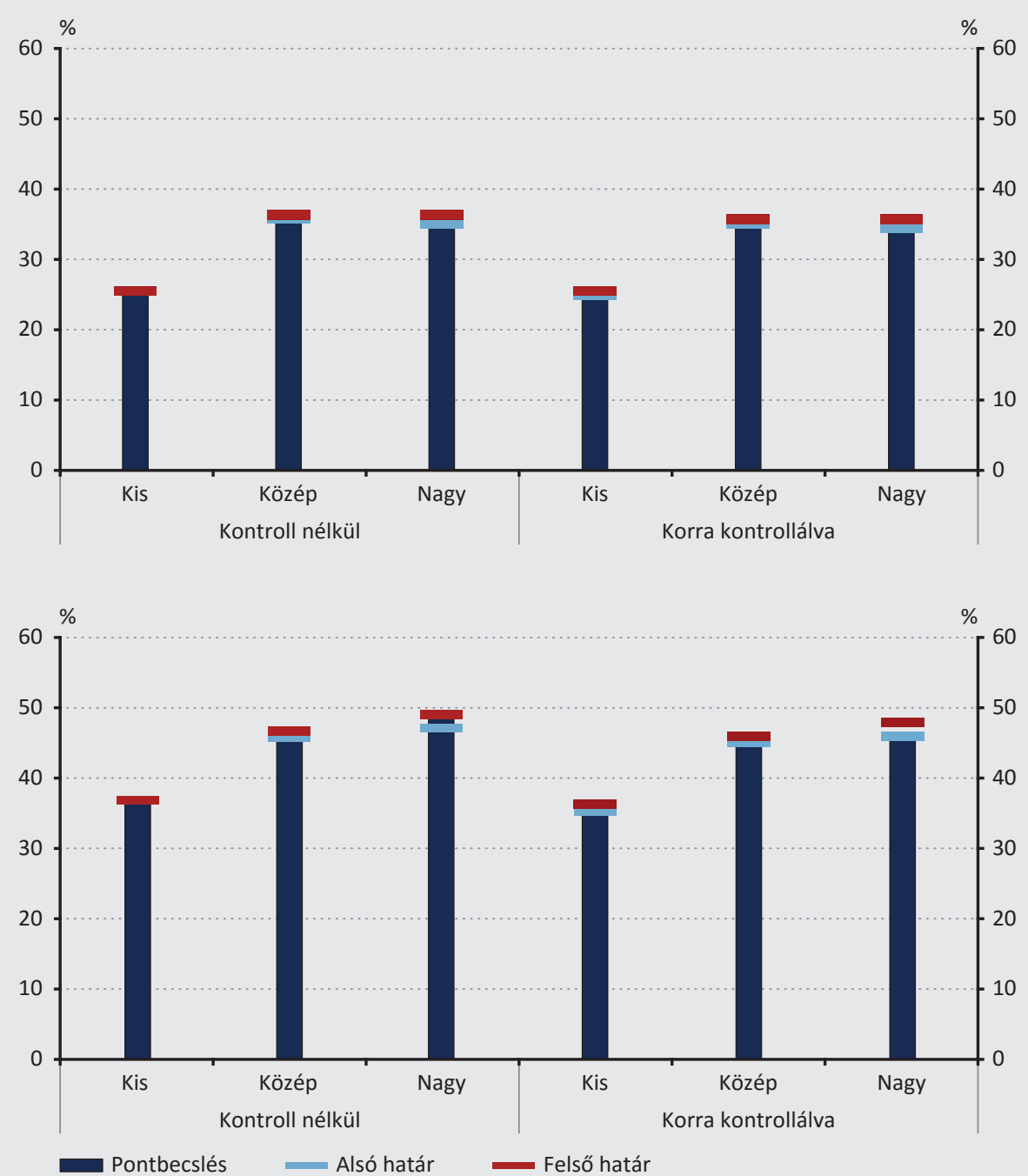

Megjegyzés: A bankhitellel rendelkezés lineáris valószínüségi modelljének becslése súlyozatlan regreszszióval. A kontrollcsoport a mikrovállalatok csoportja. Év és 2 számjegyú ágazati dummykat szerepeltetünk. Az alsó és felső határok a 95 százalékos konfidencia-intervallum határait jelentik. 
Láttuk, hogy mind a kor, mind a méret számít a hitelfelvétel esetében. Ugyanakkor a parciális $\mathrm{R}^{2}$-eket összehasonlítva azt kapjuk, hogy a méretnek sokkal nagyobb a magyarázó ereje, mint a kornak.

\section{Következtetések}

Ebben a tanulmányban számos stilizált tényt mutattunk be a magyar vállalati dinamikáról, foglalkoztunk azzal a kérdéssel, hogy a kornak vagy a vállalat méretnek van meghatározó szerepe a növekedésben, illetve megvizsgáltuk a legutóbbi pénzügyi válságban végbement vállalati alkalmazkodást.

Eredményeink szerint a fiatal vállalatok jellemzően kicsik; a méret és a kor erősen korrelál. A fiatal vállalatok gyorsabban nőnek, ugyanakkor magas közöttük a megszúnő vállalatok aránya és a teljesítményük szóródik. A kor fontosabb a méretnél a vállalatok dinamikájának magyarázatában.

A fiatal (1-4 éves) vállalatok kiugróan magas növekedésük miatt az aggregált növekedés szempontjából is fontosak: bár alacsony a részesedésük az aggregált kibocsátásból, az aggregált növekedés majdnem 70 százaléka hozzájuk füződik. A történet némileg különbözik az export esetében, ahol az idősebb vállalatok dinamikusabbak maradnak, így az aggregált exportnövekedéshez való hozzájárulásuk is sokkal nagyobb.

Amikor növekedési ráták helyett szinteket vizsgálunk, így pl. a termelékenység szintjét vagy a banki hitelkapcsolat valószínúségét, akkor azt találjuk, hogy ezeket inkább a méret határozza meg a vállalat kora helyett. Ahogy a vállalatok öregszenek, hitelképesebbé és termelékenyebbé válnak, de a méret többet magyaráz a vállalatok közötti szóródásból.

A válság során az alkalmazkodás kor és méret szerint heterogén volt. A reál hozzáadott érték esését a válságban, majd emelkedését a kilábalás során az idősebb vállalatok romló majd javuló teljesítménye határozta meg, miközben a fiatal vállalatok növekedési hozzájárulása pozitív maradt. Az alkalmazkodás mind az extenzív, mind az intenzív határon végbement - kevesebb vállalatot hoztak létre, több szúnt meg, a hozzáadott érték teremtése gyengült, annak rombolása növekedett. A heterogenitást a hitelpiacon is megfigyelhetjük, a visszaesés a hitelezésben a fiatalabbakat és idősebbeket súlyosabban érintette a középkorú vállalatokhoz képest. A koreloszlás két végén az okok különbözhetnek a kínálatot, ill. keresletet tekintve.

Érdekes módon a kilábalást a vállalati sokaság eloszlásának alsó széle dominálta: a rombolás gyengült, és kevesebb vállalat lépett ki, de a bruttó teremtésben - vállalatalapításban, növekedési kedvben és képességben - nem volt javulás. A vállalatok belépésének növekedési hozzájárulása tovább csökkent a kilábalás időszakában 
is, ami még az exportteljesítményre is érvényes. Tekintve, hogy a fiatal vállalatok mennyire fontosak a növekedés szempontjából, a belépések tartós gyengesége hozzájárulhatott a kilábalás elhúzódásához. Jövőbeli kutatás tárgya lehet annak vizsgálata, hogy mi okozta a vállalatalapítási és növekedési szándék, illetve képesség tartós gyengeségét - a bizonytalanság, a vállalatalapítás szabályainak változása, vagy a finanszírozási korlátok.

Tanulmányunk leíró természetű. Az oksági vizsgálatok és néhány kérdés mélyebb elemzése - pl. a belépési ráta tartós esése, a banki kínálati sokkok hatása - jövőbeli kutatási témaként szolgálhat. A kutatás fontos kiterjesztése lehet még a reallokációs számítások frissítése és a válság alatti teremtő rombolás vizsgálata.

\section{Felhasznált irodalom}

Aghion, P. - Akcigit, U. - Howitt, P. (2014): What Do We Learn from Schumpeterian Growth Theory? In: Handbook of Economic Growth, Elsevier, ed. 1, vol. 2, nr. 2.

Andersson, L. F. (2006): Firm demography and aggregate productivity growth. ITPS, Swedish Institute for Growth Policy Studies.

Bauer Péter - Endrész Marianna (2017): Corporate Investment in Hungary - Stylized facts on Micro Data. MNB Occasional Papers 131.

Bartelsman, E. - Haltiwanger, J. - Scarpetta, S. (2004): Microeconomic evidence of creative destruction in industrial and developing countries. World Bank Policy Research Working Paper Series, number 3464.

Békés Gábor - Halpern László - Muraközy Balázs (2011): A teremtő rombolás szerepe a vállalati termelékenység alakulásában Magyarországon. Közgazdasági Szemle, 58(2): 111-132.

Berthou, A. - Vicard, V. (2015): Firms' Export Dynamics: Experience Versus Size. The World Economy, Wiley Blackwell, 38(7): 1130-1158. https://doi.org/10.1111/twec.12221

Benk Szilárd - Morvay Endre - Telegdy Álmos (2018): KKV-k és nagyvállalatok: hogyan járulnak hozzá a munkahelyteremtéshez? Szakmai cikk, Magyar Nemzeti Bank. https://www.mnb.hu/letoltes/benk-morvay-telegdy-kkv-k-es-nagyvallalatok-hogyanjarulnak-hozza-a-munkahelyt-mnb-honlapra.pdf

Brown, J. D. - Earle, J. S. (2008): Understanding the Contributions of Reallocation to Productivity Growth: Lessons from a Comparative Firm-Level Analysis. IZA Discussion Paper. No. 3683. https://doi.org/10.17848/wp08-141

Bulan, L. - Yan, Z. (2010): Firm Maturity and the Pecking Order Theory. International Journal of Business and Economics, 9(3): 179-200. https://doi.org/10.2139/ssrn.1760505 
Castro, P. - Tascon, M.T. - Tapia, B.A. (2014): The role of life cycle on the firm's capital structure. Pecvnia, nr. 19.

Clementi, G. L. - Palazzo, B. (2016): Entry, Exit, Firm Dynamics, and Aggregate Fluctuations. American Economic Journal: Macroeconomics, 8(3): 1-41. https://doi.org/10.1257/ mac.20150017

Clementi, G. L. - Palazzo, B. - Wu, P. (2017): Firm Demographics and the Great Recession. Manuscript. Version: August 23.

Criscuolo, C. - Gal, P. N. - Menon, C. (2014): The Dynamics of Employment Growth: New Evidence from 18 countries. CEP Discussion Paper No 1274.

Davis, S. - Haltiwanger, J. - Schuh, S. (1996): Small Business and Job Creation: Dissecting the Myth and Reassessing the Facts. Small Business Economics, Springer, 8(4): 297-315. https://doi.org/10.1007/BF00393278

Gomis, R.M. - Khatiwida, S. (2017): Firm dynamics and business cycle: What doesn't kill you makes you stronger. IHEID WP No 03.

Gourio, F. - Messer, T. - Siemer, M. (2016): Firm Entry and Macroeconomic Dynamics: A State-Level Analysis. American Economic Review: Papers \& Proceedings, 106(5): 214218. https://doi.org/10.1257/aer.p20161052

Haltiwanger, J. - Jarmin, R. S. - Miranda, J. (2013): Who creates jobs? Small versus large versus young. The Review of Economics and Statistics, 95(2): 347-361. https://doi.org/ 10.1162/REST_a_00288

Haltiwanger, J. - Jarmin, R. S. - Kulick, R. - Miranda, J. (2016): High Growth Young Firms: Contribution to Job, Output and Productivity Growth. Center for Economic Studies Research Papers. CES 16-49. November.

López-Garcia, P. - Puente, S. (2006): Business Demography in Spain: Determinants of Firm Survival. Banco de España, Documentos de Trabajo, No. 0608. https://doi.org/10.2139/ ssrn.901153

MNB (2015): Növekedési jelentés. 3. fejezet. Magyar Nemzeti Bank, Budapest. MNB (2017): Növekedési jelentés. 2. fejezet. Magyar Nemzeti Bank, Budapest. OECD (2017): OECD Compendium of Productivity Indicators 2017. 


\section{Függelék}

\begin{tabular}{|c|c|c|c|c|c|c|}
\hline \multicolumn{7}{|c|}{$\begin{array}{l}\text { 1. táblázat } \\
\text { Regressziós eredmények }\end{array}$} \\
\hline \multirow{2}{*}{$\begin{array}{c}\text { Függő változó } \\
\text { VÁLTOZÓK }\end{array}$} & \multicolumn{6}{|c|}{ Rva-növekedés } \\
\hline & teljes minta & teljes minta & válság előtt & válság & kilábalás & teljes minta \\
\hline kor = 2 év & & $\begin{array}{l}1,023 * * * \\
{[0,0233]}\end{array}$ & $\begin{array}{c}1,022 * * * \\
{[0,0368]}\end{array}$ & $\begin{array}{c}1,070 * * * \\
{[0,0424]}\end{array}$ & $\begin{array}{c}0,987 * * * \\
{[0,0304]}\end{array}$ & $\begin{array}{c}0,982 * * * \\
{[0,0233]}\end{array}$ \\
\hline kor = 3 év & & $\begin{array}{c}0,249 * * * \\
{[0,0198]}\end{array}$ & $\begin{array}{c}0,295 * * * \\
{[0,0256]}\end{array}$ & $\begin{array}{c}0,237 * * * \\
{[0,0391]}\end{array}$ & $\begin{array}{c}0,177 * * * \\
{[0,0273]}\end{array}$ & $\begin{array}{c}0,214 * * * \\
{[0,0194]}\end{array}$ \\
\hline kor = 4 év & & $\begin{array}{c}0,118 * * * \\
{[0,0274]}\end{array}$ & $\begin{array}{c}0,190 * * * \\
{[0,0256]}\end{array}$ & $\begin{array}{c}0,0865 \\
{[0,0588]}\end{array}$ & $\begin{array}{c}0,0371 \\
{[0,0560]}\end{array}$ & $\begin{array}{c}0,0876 * * * \\
{[0,0259]}\end{array}$ \\
\hline kor $=5$ év & & $\begin{array}{c}0,160 * * * \\
{[0,0261]}\end{array}$ & $\begin{array}{c}0,229 * * * \\
{[0,0431]}\end{array}$ & $\begin{array}{c}0,0797 * * \\
{[0,0330]}\end{array}$ & $\begin{array}{l}0,183^{* *} \\
{[0,0721]}\end{array}$ & $\begin{array}{c}0,134 * * * \\
{[0,0258]}\end{array}$ \\
\hline kor $=6$ év & & $\begin{array}{c}0,0805^{* * *} \\
{[0,0234]} \\
\end{array}$ & $\begin{array}{c}0,141 * * * \\
{[0,0445]}\end{array}$ & $\begin{array}{l}0,0427^{*} \\
{[0,0237]} \\
\end{array}$ & $\begin{array}{c}0,0225 \\
{[0,0304]}\end{array}$ & $\begin{array}{c}0,0574 * * \\
{[0,0228]}\end{array}$ \\
\hline kor = 7 év & & $\begin{array}{c}0,0767 * * * \\
{[0,0162]} \\
\end{array}$ & $\begin{array}{c}0,114 * * * \\
{[0,0293]}\end{array}$ & $\begin{array}{l}0,0474 * \\
{[0,0248]}\end{array}$ & $\begin{array}{c}0,0645 * * * \\
{[0,0241]}\end{array}$ & $\begin{array}{c}0,0559 * * * \\
{[0,0157]}\end{array}$ \\
\hline kor = 8 év & & $\begin{array}{c}0,0596 * * * \\
{[0,0225]}\end{array}$ & $\begin{array}{c}0,108 * * * \\
{[0,0388]}\end{array}$ & $\begin{array}{c}0,0681 * * * \\
{[0,0216]}\end{array}$ & $\begin{array}{l}-0,0329 \\
{[0,0461]}\end{array}$ & $\begin{array}{l}0,0421 * \\
{[0,0221]}\end{array}$ \\
\hline kor $=9$ év & & $\begin{array}{l}0,0348 * \\
{[0,0193]}\end{array}$ & $\begin{array}{c}0,0943 * * * \\
{[0,0219]}\end{array}$ & $\begin{array}{c}-0,0422 \\
{[0,0566]}\end{array}$ & $\begin{array}{c}0,0466 * * \\
{[0,0182]}\end{array}$ & $\begin{array}{c}0,0205 \\
{[0,0188]}\end{array}$ \\
\hline kor = 10 év & & $\begin{array}{c}0,0572 * * * \\
{[0,0154]}\end{array}$ & $\begin{array}{c}0,0771^{* * *} \\
{[0,0233]}\end{array}$ & $\begin{array}{l}0,103 * * \\
{[0,0402]}\end{array}$ & $\begin{array}{c}0,0404 * * \\
{[0,0165]}\end{array}$ & $\begin{array}{c}0,0447 * * * \\
{[0,0154]}\end{array}$ \\
\hline kor = 11 év & & $\begin{array}{c}0,003 \\
{[0,0181]}\end{array}$ & $\begin{array}{c}0,0416 \\
{[0,0269]}\end{array}$ & $\begin{array}{l}-0,0598^{*} \\
{[0,0363]}\end{array}$ & $\begin{array}{c}0,0526 * * \\
{[0,0208]}\end{array}$ & $\begin{array}{l}-0,00827 \\
{[0,0179]}\end{array}$ \\
\hline kor = 12 év & & $\begin{array}{c}0,0313^{* *} \\
{[0,0145]}\end{array}$ & $\begin{array}{c}0,0504 * * \\
{[0,0236]}\end{array}$ & $\begin{array}{l}0,0408^{*} \\
{[0,0227]}\end{array}$ & $\begin{array}{l}0,0393 * \\
{[0,0211]}\end{array}$ & $\begin{array}{c}0,021 \\
{[0,0144]}\end{array}$ \\
\hline kor = 13 év & & $\begin{array}{c}0,0199 \\
{[0,0139]}\end{array}$ & $\begin{array}{l}0,0392 * \\
{[0,0234]}\end{array}$ & $\begin{array}{c}0,0268 \\
{[0,0171]}\end{array}$ & $\begin{array}{l}0,00362 \\
{[0,0239]} \\
\end{array}$ & $\begin{array}{c}0,0115 \\
{[0,0139]}\end{array}$ \\
\hline kor = 14 év & & $\begin{array}{c}0,029 \\
{[0,0235]}\end{array}$ & $\begin{array}{c}0,0568 \\
{[0,0377]}\end{array}$ & $\begin{array}{l}0,00488 \\
{[0,0212]} \\
\end{array}$ & $\begin{array}{c}0,0164 \\
{[0,0290]}\end{array}$ & $\begin{array}{c}0,0227 \\
{[0,0235]}\end{array}$ \\
\hline méret $=$ kis & $\begin{array}{c}0,0418^{* * *} \\
{[0,0028]} \\
\end{array}$ & $\begin{array}{c}0,0887 * * * \\
{[0,0034]}\end{array}$ & $\begin{array}{c}0,0830 * * * \\
{[0,0051]}\end{array}$ & $\begin{array}{c}0,103 * * * \\
{[0,0057]}\end{array}$ & $\begin{array}{c}0,0749 * * * \\
{[0,0066]}\end{array}$ & \\
\hline méret = közép & $\begin{array}{c}0,0421 * * * \\
{[0,0045]}\end{array}$ & $\begin{array}{c}0,108 * * * \\
{[0,0058]}\end{array}$ & $\begin{array}{c}0,110 * * * \\
{[0,0089]}\end{array}$ & $\begin{array}{c}0,128 * * * \\
{[0,0101]} \\
\end{array}$ & $\begin{array}{c}0,0741 * * * \\
{[0,0106]}\end{array}$ & \\
\hline méret = nagy & $\begin{array}{c}0,0535^{* * *} \\
{[0,0087]}\end{array}$ & $\begin{array}{c}0,130 * * * \\
{[0,0103]}\end{array}$ & $\begin{array}{c}0,143 * * * \\
{[0,0172]}\end{array}$ & $\begin{array}{c}0,158 * * * \\
{[0,0173]}\end{array}$ & $\begin{array}{c}0,0747 * * * \\
{[0,0180]}\end{array}$ & \\
\hline Megfigyelések & 3867153 & 3867153 & 1491393 & 1455747 & 920013 & 3867153 \\
\hline R-négyzet & 0,018 & 0,061 & 0,061 & 0,075 & 0,053 & 0,057 \\
\hline
\end{tabular}

Megjegyzés: A zárójelekben robusztus sztenderd hibák szerepelnek. ${ }^{* * *} p<0,01 ; * * p<0,05 ;{ }^{*} p<0,1$. 2 számjegyú ágazati és év fixed hatásokat tartalmaz. A kontrollcsoport a kor esetében a 15+, a méretre a mikrovállalatok. 


\begin{tabular}{|c|c|c|c|c|c|c|c|}
\hline \multicolumn{8}{|c|}{$\begin{array}{l}\text { 1. táblázat } \\
\text { Regressziós eredmények - folytatás }\end{array}$} \\
\hline \multirow{2}{*}{$\begin{array}{l}\text { Függő változó } \\
\text { VÁLTOZóK }\end{array}$} & \multirow{2}{*}{$\begin{array}{c}\text { Munka- } \\
\text { termelé- } \\
\text { kenység }\end{array}$} & \multirow{2}{*}{\begin{tabular}{|c|}
$\begin{array}{c}\text { Export- } \\
\text { növekedés }\end{array}$ \\
teljes minta
\end{tabular}} & \multicolumn{3}{|c|}{ Rendelkezik bankhitellel } & \multicolumn{2}{|c|}{ Felvesz új bankhitelt } \\
\hline & & & teljes minta & teljes minta & teljes minta & teljes minta & teljes minta \\
\hline \multirow[t]{2}{*}{ kor $=2$ év } & $-0,461 * * *$ & $1,035^{* * *}$ & $-0,158 * * *$ & $-0,118^{* * *}$ & & & $-0,0279 * * *$ \\
\hline & {$[0,0303]$} & {$[0,0527]$} & {$[0,0007]$} & {$[0,0006]$} & & & {$[0,0005]$} \\
\hline \multirow[t]{2}{*}{ kor $=3$ év } & $-0,274^{* * *}$ & $0,256 * * *$ & $-0,104 * * *$ & $-0,0688 * * *$ & & & $-0,0169 * * *$ \\
\hline & {$[0,0294]$} & {$[0,0666]$} & {$[0,0007]$} & {$[0,0007]$} & & & {$[0,0005]$} \\
\hline \multirow[t]{2}{*}{ kor $=4$ év } & $-0,185^{* * *}$ & $0,196 * * *$ & $-0,0637^{* * *}$ & $-0,0304^{* * *}$ & & & $-0,00999 * * *$ \\
\hline & {$[0,0287]$} & {$[0,0693]$} & {$[0,0008]$} & {$[0,0008]$} & & & {$[0,0006]$} \\
\hline \multirow[t]{2}{*}{ kor $=5$ év } & $-0,116^{* * *}$ & $0,160 * * *$ & $-0,0368 * * *$ & $-0,00586 * * *$ & & & $-0,00611^{* * *}$ \\
\hline & {$[0,0306]$} & {$[0,0496]$} & {$[0,0009]$} & {$[0,0009]$} & & & {$[0,0006]$} \\
\hline \multirow[t]{2}{*}{ kor $=6$ év } & $-0,0867^{* * *}$ & $0,211 * * *$ & $-0,0210 * * *$ & $0,00770 * * *$ & & & $-0,00483^{* * *}$ \\
\hline & {$[0,0321]$} & {$[0,0628]$} & {$[0,0009]$} & {$[0,0009]$} & & & {$[0,0006]$} \\
\hline \multirow[t]{2}{*}{ kor $=7$ év } & $-0,0489$ & $0,0825^{*}$ & $-0,0147 * * *$ & $0,0118 * * *$ & & & $-0,00478 * * *$ \\
\hline & {$[0,0311]$} & {$[0,0483]$} & {$[0,00098]$} & {$[0,0009]$} & & & {$[0,0007]$} \\
\hline \multirow[t]{2}{*}{ kor $=8$ év } & $-0,125^{*}$ & 0,0299 & $-0,0117^{* * *}$ & $0,0132 * * *$ & & & $-0,00571 * * *$ \\
\hline & {$[0,0759]$} & {$[0,0323]$} & {$[0,0010]$} & {$[0,00098]$} & & & {$[0,0007]$} \\
\hline \multirow[t]{2}{*}{ kor = 9 év } & $-0,0292$ & 0,0116 & $-0,0104 * * *$ & $0,0124 * * *$ & & & $-0,00513 * * *$ \\
\hline & {$[0,0318]$} & {$[0,0351]$} & {$[0,0010]$} & {$[0,0010]$} & & & {$[0,0007]$} \\
\hline \multirow[t]{2}{*}{ kor = 10 év } & $-0,016$ & $0,0838 * *$ & $-0,0102 * * *$ & $0,0110 * * *$ & & & $-0,00509 * * *$ \\
\hline & {$[0,0289]$} & {$[0,0365]$} & {$[0,00101]$} & {$[0,0010]$} & & & {$[0,0007]$} \\
\hline \multirow[t]{2}{*}{ kor = 11 év } & 0,00224 & $-0,0101$ & $-0,0115^{* * *}$ & $0,00794 * * *$ & & & $-0,00370 * * *$ \\
\hline & {$[0,0282]$} & {$[0,0451]$} & {$[0,0011]$} & {$[0,0010]$} & & & {$[0,0007]$} \\
\hline \multirow[t]{2}{*}{ kor = 12 év } & 0,0189 & $0,0880^{*}$ & $-0,0159 * * *$ & $0,00227^{* *}$ & & & $-0,00417 * * *$ \\
\hline & {$[0,0273]$} & {$[0,0502]$} & {$[0,0011]$} & {$[0,0010]$} & & & {$[0,0007]$} \\
\hline \multirow[t]{2}{*}{ kor $=13$ év } & 0,00891 & $-0,0189$ & $-0,0162 * * *$ & $-0,00011$ & & & $-0,00360 * * *$ \\
\hline & {$[0,0305]$} & {$[0,0330]$} & {$[0,0011]$} & {$[0,0010]$} & & & {$[0,0007]$} \\
\hline \multirow[t]{2}{*}{ kor $=14$ év } & $-0,0306$ & $-0,0218$ & $-0,0162^{* * *}$ & $-0,00285^{* * *}$ & & & $-0,00342 * * *$ \\
\hline & {$[0,0612]$} & {$[0,0295]$} & {$[0,0011]$} & {$[0,0011]$} & & & {$[0,0008]$} \\
\hline \multirow[t]{2}{*}{ méret $=$ kis } & $0,360 * * *$ & $0,266 * * *$ & & $0,362 * * *$ & $0,371 * * *$ & $0,254 * * *$ & $0,252 * * *$ \\
\hline & {$[0,0397]$} & {$[0,0148]$} & & {$[0,0009]$} & {$[0,0009]$} & {$[0,0008]$} & {$[0,0008]$} \\
\hline \multirow[t]{2}{*}{ méret = közép } & $0,707^{* * *}$ & $0,333 * * *$ & & $0,454^{* * *}$ & $0,465^{* * *}$ & $0,358 * * *$ & $0,354^{* * *}$ \\
\hline & {$[0,00734]$} & {$[0,0168]$} & & {$[0,0018]$} & {$[0,0018]$} & {$[0,0019]$} & {$[0,0019]$} \\
\hline \multirow[t]{2}{*}{ méret = nagy } & $0,888 * * *$ & $0,392 * * *$ & & $0,469 * * *$ & $0,482 * * *$ & $0,356 * * *$ & $0,352 * * *$ \\
\hline & {$[0,0151]$} & {$[0,0213]$} & & {$[0,0038]$} & {$[0,0038]$} & {$[0,0041]$} & {$[0,0041]$} \\
\hline Megfigyelések & 3152913 & 507326 & 4183013 & 4183013 & 4183013 & 4183013 & 4183013 \\
\hline R-négyzet & 0,258 & 0,075 & 0,062 & 0,131 & 0,123 & 0,108 & 0,109 \\
\hline
\end{tabular}

Megjegyzés: A zárójelekben robusztus sztenderd hibák szerepelnek. *** $p<0,01 ; * * p<0,05 ;{ }^{*} p<0,1$. 2 számjegyú ágazati és év fixed hatásokat tartalmaz. A kontrollcsoport a kor esetében a 15+, a méretre a mikrovállalatok. 